\title{
OSTI
}

\section{Geographic Patterns of Carbon Dioxide Emissions from Fossil-Fuel Burning, Hydraulic Cement Production, and Gas Flaring on a One Degree by One Degree Grid Cell Basis: 1950 to 1990}

\author{
R. J. Andres \\ University of Alaska, Fairbanks \\ G. Marland \\ Oak Ridge National Laboratory \\ I. Fung and E. Matthews \\ Godddard Institute for Space Studies
}

A. L. Brenkert, Editor

Carbon Dioxide Information Analysis Center
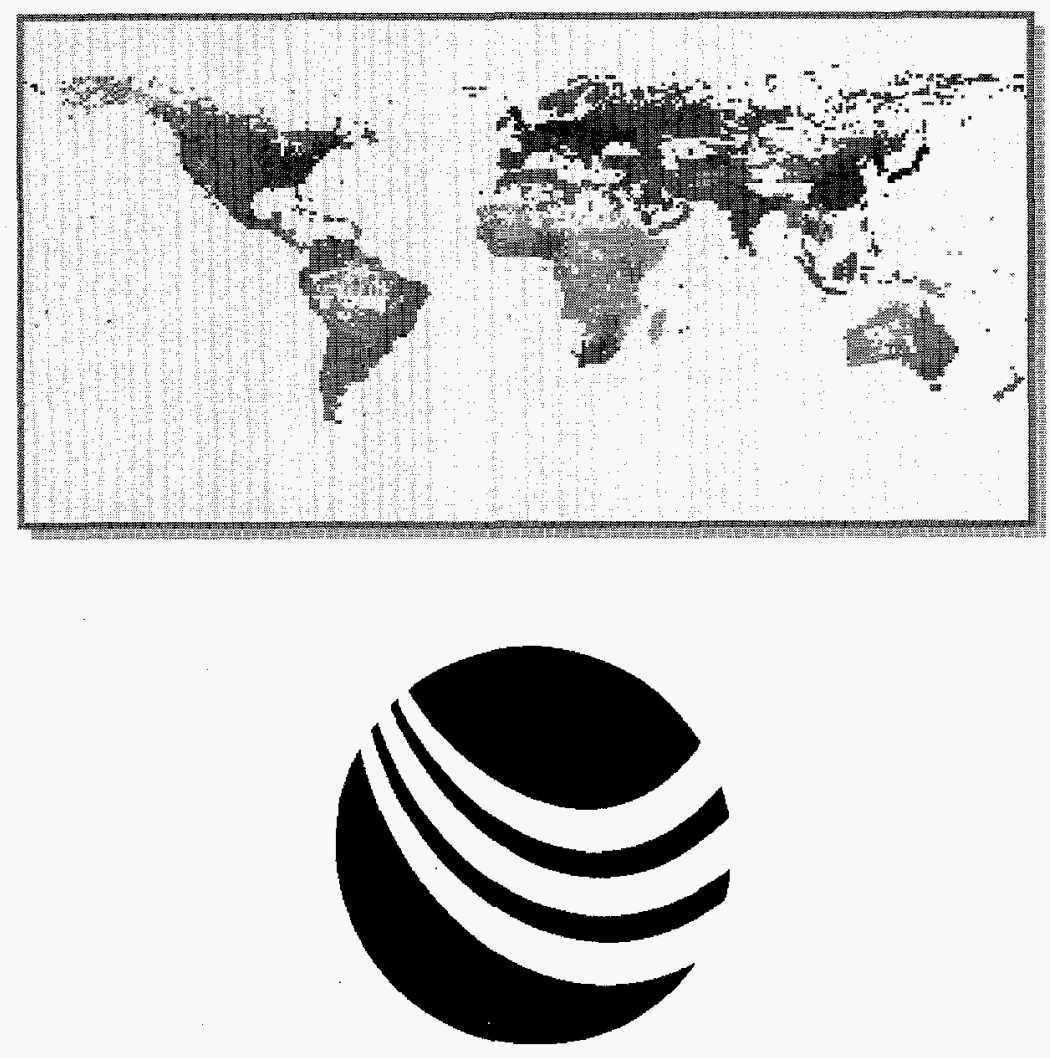

Carbon Dioxide Information Analysis Center

Oak Ridge National Laboratory

Environmental Sciences Division

Publication No. 4646

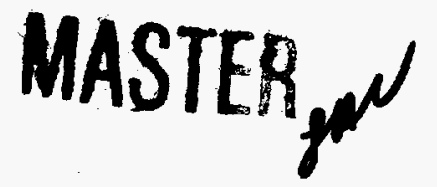


This report has ben reproduced directly from the best available copy.

Available to DOE and DOE contractors from the Office of Scientific and Technical Information, P.O. Box 62, Oak Ridge, TN 37831; prices available from (423) 576-8401, FTS 626-8401.

Available to the public from the National Technical Information Service, U.S. Department of Commerce, 5285 Port Royal Rd., Springfield, VA 22161.

This report was prepared as an account of work sponsored by an agency of the United States Government. Neither the United States Government nor any agency thereof, nor any of their employees, makes any warranty, express or implied, or assumes any legal liability or responsibility for the accuracy, completeness, or usefulness of any information, apparatus, product, or process disclosed, or represents that its use would not intringe privately owned rights. Reference herein to any specific commercial product, process, or service by trade name, trademark, manufacturer, or otherwise, does not necessarily constitute or imply its endorsement, recommendation, or favoring by the United States Government or any agency thereot. The views and opinions of authors expressed herein do not necessarily state or reflect those of the United States Government or any agency thereof. 


\section{DISCLAIMER}

Portions of this document may be illegible electronic image products. Images are produced from the best available original document. 
Geographic Patterns of Carbon Dioxide Emissions from Fossil-Fuel Burning, Hydraulic Cement Production, and Gas Flaring on a One Degree by One Degree Grid Cell Basis: 1950 to 1990

Contributed by

Robert J. Andres

Institute of Northern Engineering, School of Engineering

University of Alaska Fairbanks, Fairbanks, Alaska

Gregg Marland

Environmental Sciences Division

Oak Ridge National Laboratory, Oak Ridge, Tennessee

Inez Fung ${ }^{1}$

University of Victoria, British Columbia, Canada

Elaine Matthews ${ }^{1}$

Columbia University, New York, New York

${ }^{1}$ National Aeronautics and Space Administration

Goddard Institute for Space Studies

New York, New York

Prepared by Antoinette L. Brenkert

Carbon Dioxide Information Analysis Center

Oak Ridge National Laboratory, Oak Ridge, Tennessee

Environmental Sciences Division, Publication No. 4646

Date Published: March 1997

Prepared for the

Global Change Research Program

Environmental Sciences Division

Office of Health and Environmental Research

U.S. Department of Energy

Budget Activity Number KP 1204010

Prepared by the

OAK RIDGE NATIONAL LABORATORY

Oak Ridge, Tennessee 37831-6335

managed by

LOCKHEED MARTIN ENERGY RESEARCH CORP.

for the

U.S. DEPARTMENT OF ENERGY

under contract DE-AC05-96OR22464 


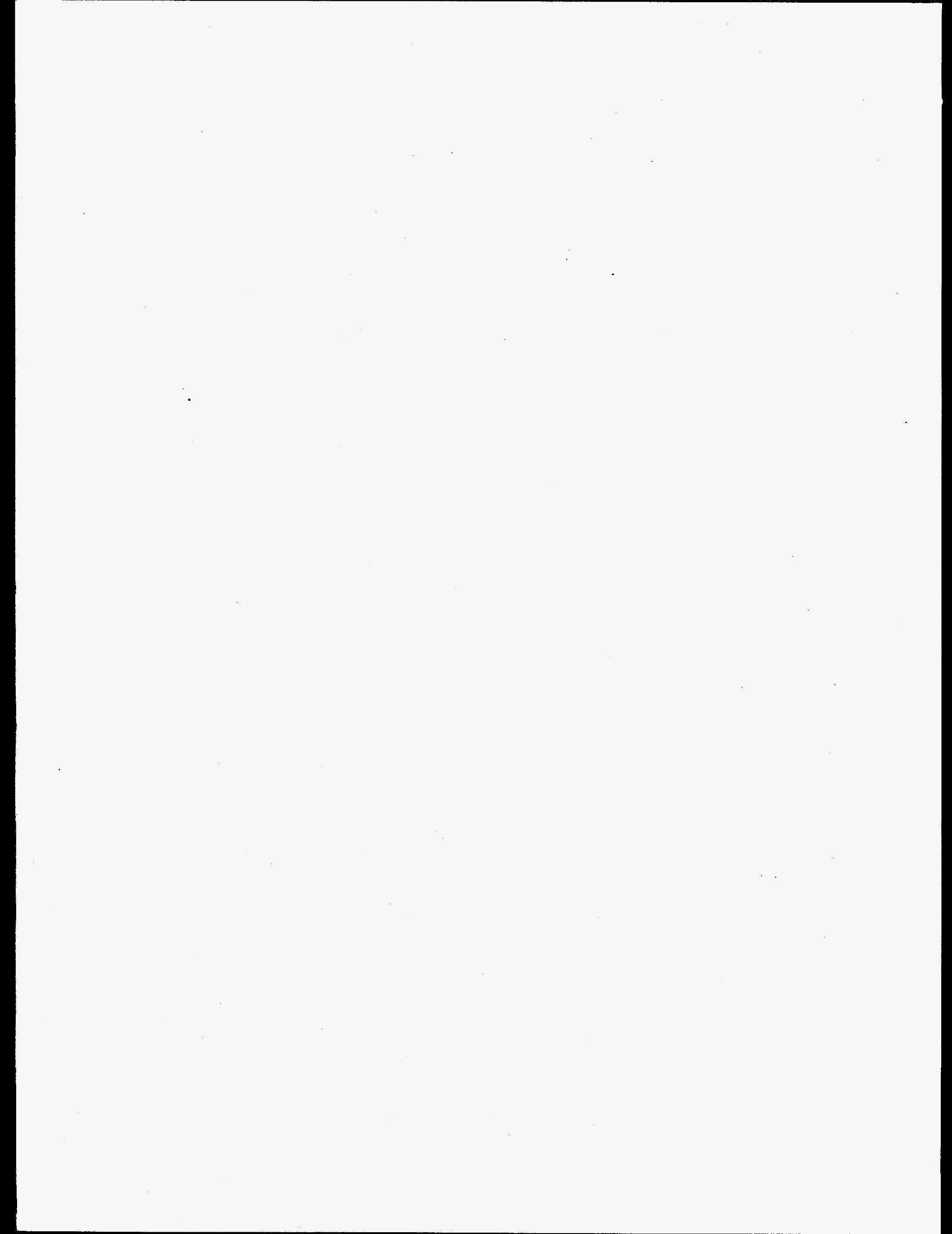




\section{CONTENTS}

LIST OF FIGURES $\ldots \ldots \ldots \ldots \ldots \ldots \ldots \ldots \ldots \ldots \ldots \ldots \ldots \ldots \ldots \ldots \ldots \ldots \ldots \ldots \ldots \ldots$

LIST OF TABLES $\ldots \ldots \ldots \ldots \ldots \ldots \ldots \ldots \ldots \ldots \ldots \ldots \ldots \ldots \ldots \ldots \ldots \ldots \ldots \ldots \ldots \ldots \ldots \ldots \ldots$

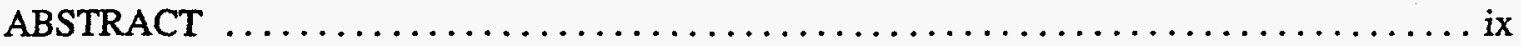

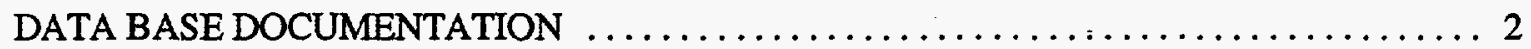

1. NAME OF THE NUMERIC DATA PACKAGE $\ldots \ldots \ldots \ldots \ldots \ldots \ldots \ldots \ldots \ldots \ldots$

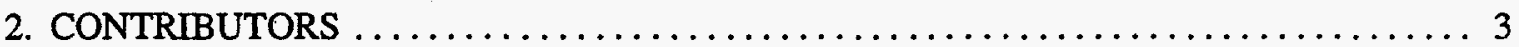

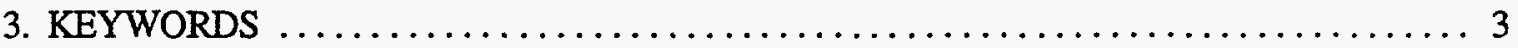

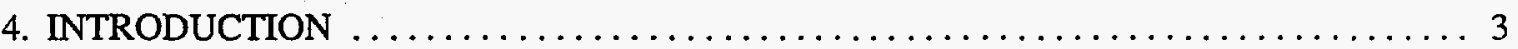

5. DESCRIPTION OF THE DATABASE, DATA SOURCES AND GRID

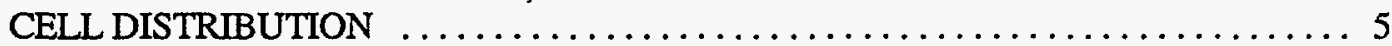

6. GLOBAL TOTALS, LATITUDINAL DISTRIBUTIONS AND CHANGES OVER TIME

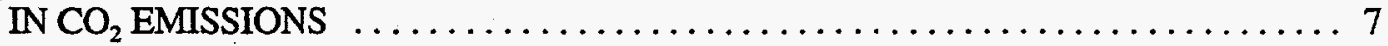

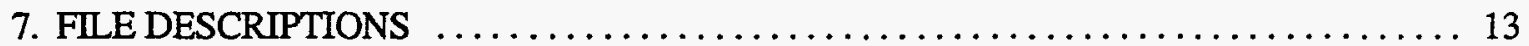

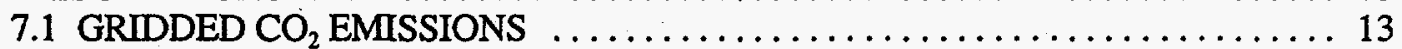

7.2 GRID CELL INFORMATION ON $\mathrm{CO}_{2}$ EMISSION, LOCATION AND

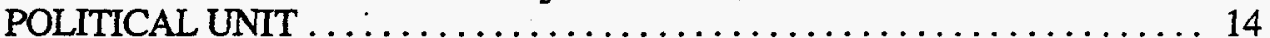

7.3 UNDERLYING DATABASES AND CODES TO CREATE THE EXTENDED GRIDDED $\mathrm{CO}_{2}$ EMISSION FILES $\ldots \ldots \ldots \ldots \ldots \ldots \ldots \ldots 15$

7.4 LATITUDINAL SUMMARY AND MAPS $\ldots \ldots \ldots \ldots \ldots \ldots \ldots \ldots \ldots \ldots$

8. CDIAC QUALITY ASSURANCE CHECKS $\ldots \ldots \ldots \ldots \ldots \ldots \ldots \ldots \ldots \ldots \ldots \ldots \ldots$

9. HOW TO OBTAIN THE DATABASE AND DOCUMENTATION $\ldots \ldots \ldots \ldots \ldots \ldots$

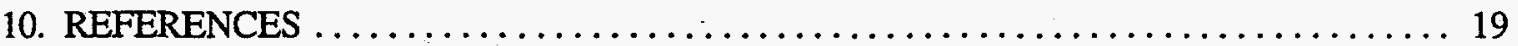

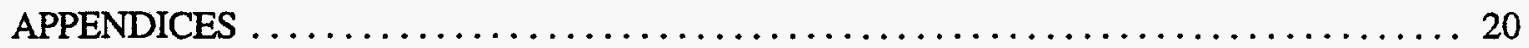

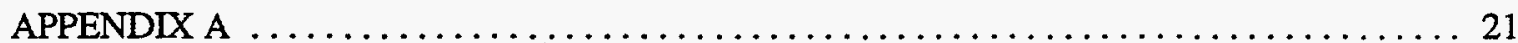

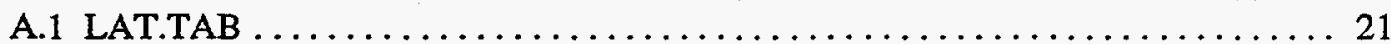

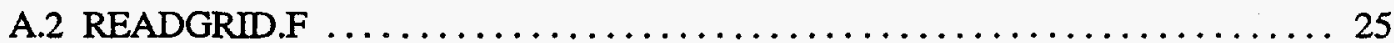

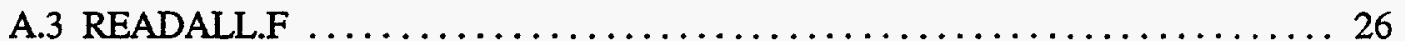

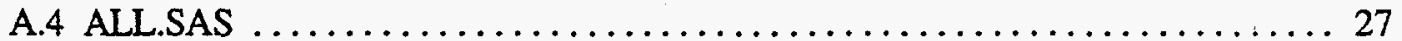

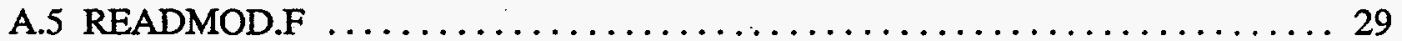

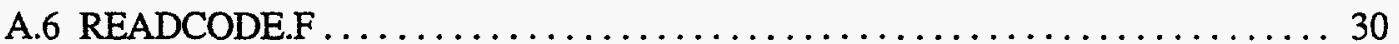

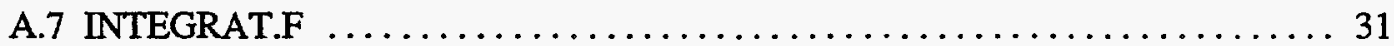

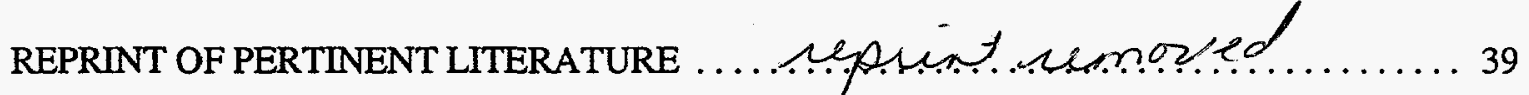

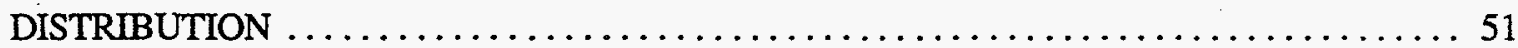


(1) 


\section{LIST OF FIGURES}

Fig. 6.1. Latitudinal distribution of decadal carbon emisions data: $1950-1990$ 9 


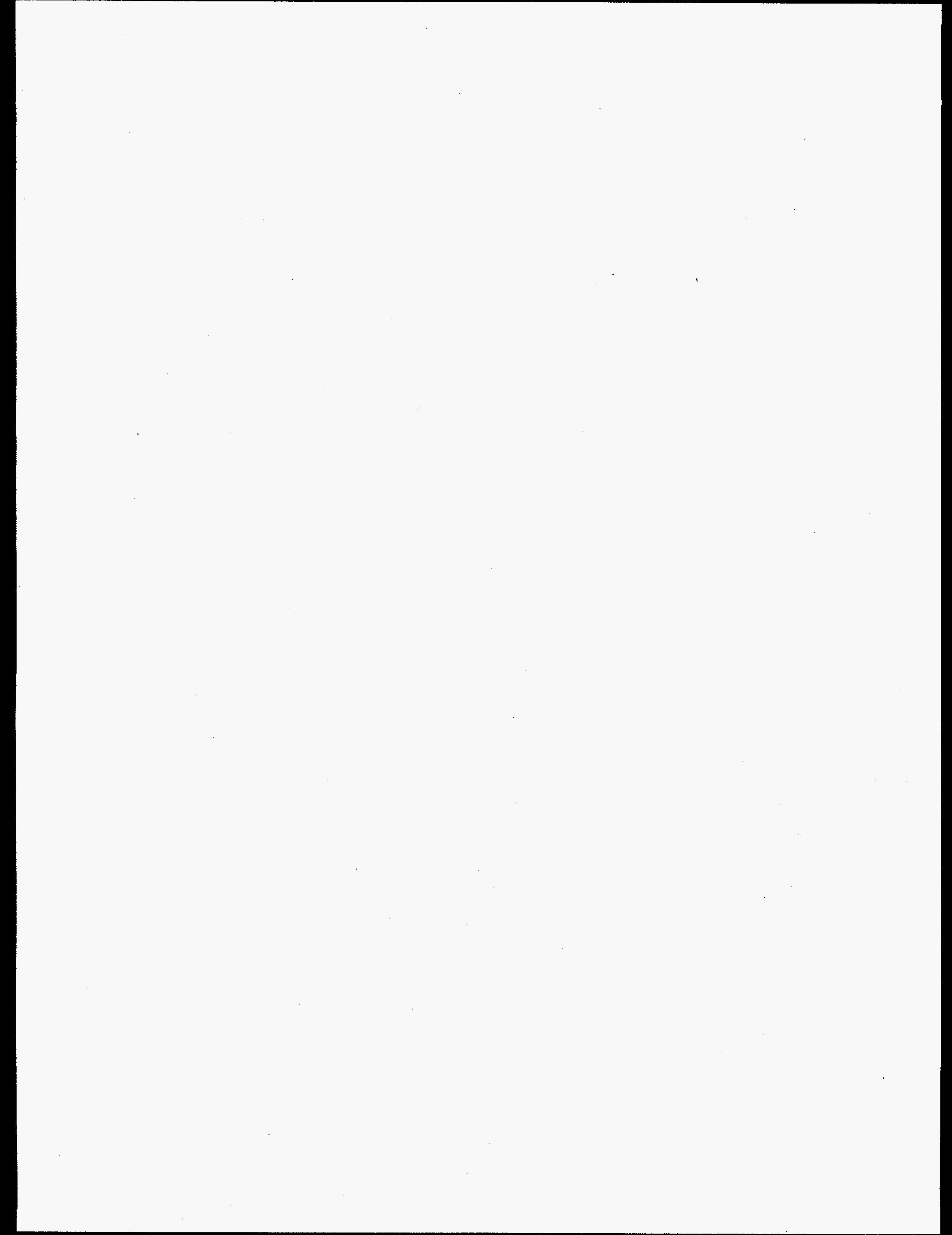




\section{LIST OF TABLES}

Table 6.1 $\mathrm{CO}_{2}$ emissions in million metric tons of $\mathrm{C}$ per year.

Table 6.2 Latitudinal emissions in units of thousand metric tons $C$ per year and the percent contribution by the major $\mathrm{CO}_{2}$ emitting countries relative to the total latitudinal $\mathrm{CO}_{2}$ emissions.

Table 6.3 Changes in fossil-fuel $\mathrm{CO}_{2}$ emissions from 1980 to 1990 in the top emitting countries

Table 6.4 Major changes in fossil-fuel emissions from 1980 to 1990 in other countries 12

Table 7.1 Single-field $\mathrm{CO}_{2}$ emission file names, sizes, types and format 13

Table 7.2 Nine-field $\mathrm{CO}_{2}$ emission file names, sizes, types and format 14

Table 7.3 Background file names, sizes, types and format 15

Table 7.4 Summary file names, sizes and types 16

Table 7.5 Overview of number of countries and political units involved 17 


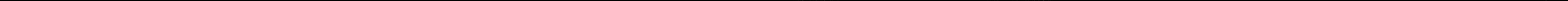




\begin{abstract}
Andres, R.J, G. Marland, I. Fung, E. Matthews and A.L. Brenkert. 1996. Geographic Patterns of Carbon Dioxide Emissions from Fossil-Fuel Burning, Hydraulic Cement Production, and Gas Flaring on a One Degree by One Degree Grid Cell Basis: 1950 to 1990. ORNL/CDIAC-97, NDP058. Carbon Dioxide Information Analysis Center, Oak Ridge National Laboratory, Oak Ridge, Tennessee, U.S.A. 56 pp.

Data sets of one degree latitude by one degree longitude carbon dioxide $\left(\mathrm{CO}_{2}\right)$ emissions in units of thousand metric tons of carbon (C) per year from anthropogenic sources have been produced for 1950, 1960, 1970, 1980 and 1990 (Andres et al., 1996). Detailed geographic information on $\mathrm{CO}_{2}$ emissions can be critical in understanding the pattern of the atmospheric and biospheric response to these emissions. Global, regional and national annual estimates for 1950 through 1992 were published previously (Boden et al., 1996). Those national, annual $\mathrm{CO}_{2}$ emission estimates were based on statistics on fossil-fuel burning, cement manufacturing and gas flaring in oil fields as well as energy production, consumption and trade data, using the methods of Marland and Rotty (1984). The national annual estimates were combined with gridded one-degree data on political units and 1984 human populations (Andres et al., 1996) to create the new gridded $\mathrm{CO}_{2}$ emission data sets. The same population distribution was used for each of the years as proxy for the emission distribution within each country. The implied assumption for that procedure was that per capita energy use and fuel mix is uniform over a political unit. The consequence of this first-order procedure is that the spatial changes observed over time are solely due to changes in national energy consumption and nation-based fuel mix. Increases in emissions over time are apparent for most areas, e.g., from 1980 and 1990, a 63\% increase in $\mathrm{CO}_{2}$ emissions (based on 1980 emissions) occurred in mainland China and a 95\% increase in India. However, actual decreases from 1980 to 1990 occurred in Western Europe, i.e., 30\% in Sweden, 27\% in France, and 23\% in Belgium. Latitudinal summations of emissions show a slow southerly shift (in the Northern Hemisphere) in the bulk of emissions over time. The large increases, from 1950 to 1990, in China's and India's contributions to anthropogenic $\mathrm{CO}_{2}$ emissions compared to those by the United States are, for example, very apparent at the latitudinal band around 25.5 degrees North.

The digital data sets are available without charge, on a variety of media and via the Internet from the Carbon Dioxide Information Analysis Center (CDIAC). Each decadal $\mathrm{CO}_{2}$-emission data file requires around 1.2 megabytes of disk storage; each decadal data file that has additional country code information requires around 7.6 megabytes of disk storage, and the graphics image format (gif) map files each require around 0.02 megabytes of disk storage.
\end{abstract}

Keywords: Carbon Dioxide Emissions; Fossil Fuel; Energy Consumption; Anthropogenic Emissions; Carbon Cycle 

DATA BASE DOCUMENTATION 


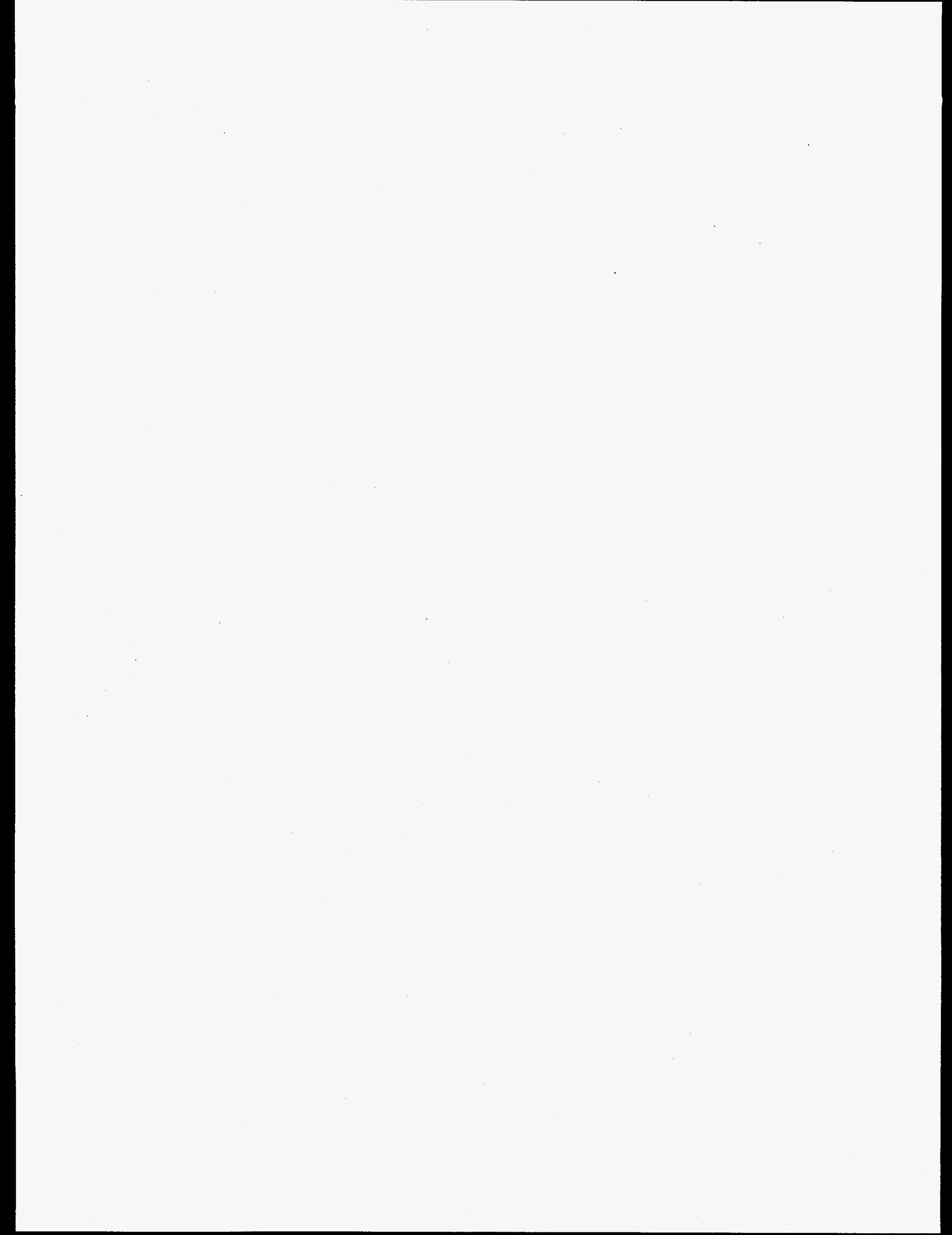


1. NAME OF THE NUMERIC DATA PACKAGE

GEOGRAPHIC PATTERNS OF CARBON DIOXIDE EMISSIONS FROM FOSSIL-FUEL BURNING, HYDRAULIC CEMENT PRODUCTION, AND GAS FLARING ON A ONE DEGREE BY ONE DEGREE GRID CELL BASIS: 1950 TO 1990

\section{CONTRIBUTORS}

Robert J. Andres

Institute of Northern Engineering, School of Engineering

University of Alaska Fairbanks, Fairbanks, Alaska

Gregg Marland

Environmental Sciences Division

Oak Ridge National Laboratory, Oak Ridge, Tennessee

Inez Fung ${ }^{1}$

School of Earth and Ocean Sciences

University of Victoria , British Columbia, Canada

Elaine Matthews ${ }^{1}$

Columbia University, New .York, New York

${ }^{1}$ National Aeronautics and Space Administration

Goddard Institute for Space Studies

New York, New York

\section{KEYWORDS}

Carbon Dioxide Emissions; Fossil Fuel; Energy Consumption; Anthropogenic Emissions; Carbon Cycle

\section{INTRODUCTION}

Annual, global carbon dioxide $\left(\mathrm{CO}_{2}\right)$ emissions from fossil-fuel burning, cement production and gas flaring show a steady increase from 1950 to 1990 (Boden et al., 1994 p. 508; Boden et al., 1996 p. 24). From 1959 through 1990 the global atmospheric $\mathrm{CO}_{2}$ concentrations increased from $316 \mathrm{ppm}$ to $354 \mathrm{ppm}$. The global, regional and national annual estimates of anthropogenic $\mathrm{CO}_{2}$ emissions expressed in units of thousand metric tons carbon (C) per year have been documented by Boden et al. (1996). The 1992 United Nations Energy Statistics Database (U.N.,1994), the hydraulic cement production estimates compiled by the U.S. Department of Interior's Bureau of Mines (Solomon, 1993), and supplemental data 
on gas flaring obtained from the U.S. Department of Energy's Energy Information Administration were processed for this purpose following the methods of Marland and Rotty (1984). Estimates of anthropogenic emissions released to the atmosphere as $\mathrm{CO}_{2}$ in 1860 amount to 93.3 million metric tons C (Keeling, 1973), in 1950 to 1638 million metric tons $C$ and in 1990 to 6099 million metric tons $C$ (Boden et al., 1996).

The database documented here presents decadal $(1950,1960,1970,1980$ and 1990) estimates of gridded fossil-fuel $\mathrm{CO}_{2}$ emissions, expressed in 1000 metric tons $\mathrm{C}$ per year per one degree latitude by one degree longitude. The $\mathrm{CO}_{2}$ emissions are the summed emissions from fossil-fuel burning, hydraulic cement production and gas flaring. The national annual estimates (Boden et al., 1996) were allocated to one degree grid cells based on gridded information on national boundaries and political units, and a 1984 gridded human population map (Andres et al., 1996). Marland et al. (1985) note that using population distribution as a proxy for the distribution of $\mathrm{CO}_{2}$ emissions within a country offers a reasonable initial approximation but carries two implied assumptions that are clearly not filled: a) that per capita energy use is uniform over a political unit, and b) that the fuel mix is constant throughout a political unit. In addition, it was assumed that the 1984 population distribution provides a useful first approximation of the within-country distribution of the $\mathrm{CO}_{2}$ emissions for each of the years between 1950 and 1990. (Note: the national $\mathrm{CO}_{2}$ emissions are U.N.- statistics-based). The consequence of this first-order procedure is that the spatial changes observed are solely due to changes over time in national energy consumption and the nation-based fuel mix.

The global $\mathrm{CO}_{2}$ emissions in this database are compared with previously published estimates. Latitudinal summations are presented in a table and graph. Maps of emission patterns are added as graphics image format (gif) files. The database is part of an attempt by CDIAC to compile an integrated network of global gridded carbon flux and carbon storage information. Locally specific information on fossil-fuel emissions might aid in analyzing global sources and sinks of $\mathrm{CO}_{2}$.

In the future we hope to have more and different information available on energy use and population density, besides the 1984 population at a one degree grid resolution, so that $\mathrm{CO}_{2}$ emission estimates can be differently distributed over grid cells than presently. Population changes at national levels and urbanization might be incorporated to get better insight into geographical shifts in fossil-fuel consumption, such that observational data on $\mathrm{CO}_{2}$-fertilization versus air pollution can be better analyzed. The available fossil-fuel emission data, broken down in consumption sectors, as in Boden et al. (1996), might be put in geographic context, and then analyzed for purposes of potential policy decisions for curtailing emissions. Previously, (Marland et al., 1985) estimated fossil-fuel emissions for 1980 at a 5 degree grid cell resolution. Fung et al. (1987; http://www.giss.nasa.gov) generated publicly available databases: a one degree gridded database from the 1987 fossil-fuel emissions (after Marland et al., 1985), a one degree gridded database from 1980 land-use change emissions (after Houghton et al., 1987), and a 4 by 5 degree gridded database of $\mathrm{CO}_{2}$ exchange of the oceans (Broecker et al., 1986). The database documented here (NDP058) handles, as the previous ones, annual information. Seasonal fossil-fuel emission might be put in a geographic referencable detailed database, both for carbon flux modeling and data analysis purposes, e.g., Fung et al. (1987) used their 4 by 5 degree gridded database of monthly $\mathrm{CO}_{2}$ exchange in their GISS 3-D global tracer transport model. Carbon isotope signatures $\left({ }^{13} \mathrm{C}^{12} \mathrm{C}\right.$ and ${ }^{14} \mathrm{C}^{12} \mathrm{C}$ data) can be incorporated as verification of fossil-fuel emission fate. Ocean isotope signature data are available, as are $\mathrm{CO}_{2}$ concentrations; these data put in a geographic grid, and analyzed could aid in the understanding of the temporal and spatial scales of the impacts of fossil-fuel emissions. 


\section{DESCRIPTION OF THE DATABASE, DATA SOURCES AND GRID CELL DISTRIBUTION}

This database (NDP058) consists of 33 files, 22 in ASCII text format and 11 in gif format listed in Tables 7.1, 7.2, 7.3 and 7.4. The database consists of this documentation file (the ndp058.doc or README file) and the files described below.

The GRIDCAR.year data consist of (five) single-field files for the years 1950, 1960, 1970, 1980 and 1990 with gridded $\mathrm{CO}_{2}$ emissions from anthropogenic sources (Table 7.1). The '1992 UN revision' data (U.N., 1994) of fossil-fuel $\mathrm{CO}_{2}$ emissions (units as 1000 metric tons $\mathrm{C}$ per year per one*one degree grid cell) are arranged sequentially as one record per line in bands starting with grid cells centered at $\mathbf{1 7 9 . 5}$ degrees West through grid cells centered at 179.5 degrees East, and from grid cells centered at 89.5 degrees North to grid cells centered at 89.5 degrees South. The FORTRAN code READGRID.F is provided to read the GRIDCAR.year data files and sum the emissions to global totals.

The GRIDALL.year data consist of (five) nine-field files for the years 1950, 1960, 1970, 1980 and 1990 (Table 7.2). Records in these files are arranged similarly from West to East and North to South. They provide the same fossil-fuel emission information but have additional location and country-code information. Grid cells are identified by the latitude and longitude coordinates of the midpoint of the grid cell and a Global Emissions Inventory Activity (GEIA)-id code. The effort to put the national annual emissions on a one degree gridded basis was a contribution to GEIA. The GEIA-id code equals [ $\left.\left(\mathrm{j}^{*} 1000\right)+\mathrm{i}\right]$, where ' $\mathrm{j}$ ' is a row number starting at 1 for the grid cell between 90 and 89 degrees South ('j' equals 180 for the grid cell between 89 and 90 degrees North) and ' $i$ ' is a column number starting at 1 for the grid cell between 180 and 179 degrees West ('i' equals 360 for the grid cell between 179 and 180 degrees East). In other words, latitude equals [(j-91)+0.5] and longitude equals [(i-181)+0.5]. Analogous to the national annual $\mathrm{CO}_{2}$ emission database (Boden et al., 1996: CDIAC NDP030/R6, Table 1 and Table 2), the gridded emission database has national identifiers in the form of the United Nations recognized country's name and the United Nations 3-digit country code for each grid cell.

A gridded population data set, with population estimates for the year 1984 was used to allocate the national annual emissions over the grid cells. The population and political unit data sets were obtained from the Goddard Institute of Space Studies (GISS). The initial NASA-GISS gridded population data set (POP1X1.1984) and the initial NASA-GISS gridded political unit data set (CNTRY1X1.1993) were adjusted by Andres et al. (1996) to ensure that for each of the dates (1950, $1960,1970,1980,1990)$ existing countries were represented, the populations were associated with the proper political units, and the available national emission estimates were properly distributed over that country's area using population.

The initial one degree gridded NASA-GISS population density data set (POP1X1.1984) describes the 1984 worldwide distribution of human population densities. It was constructed, following a method identical to Lerner et al. (1988), placing all urban centers with more than 100,000 inhabitants into the appropriate grid cells. Then, the sum of the urban populations for a political unit was subtracted from the total population for that political unit. The remaining rural and smaller urban populations were evenly distributed among cells showing human land use as defined by Matthews (1983). The aim of the NASA-GISS population density data set was to yield a geographically correct, rather than a politically correct population distribution (POP1X1.HELP). This population density data set was first converted by Andres et al. (1996) to total population per grid cell by multiplying the population density with the cell surface area. The data set was then modified by relocating 43 border urban area populations into the nearest cell identified with the correct political unit. In addition 95 coastal urban areas were 
reassigned from ocean to the correct political unit (but not moved to the nearest cell) (see also CNTRY1X1.HELP). Andres' modifications resulted in the POPMOD.DAT data file. Thus, no geographical changes of populations over time within a country or political unit were taken into account.

The initial one degree gridded NASA-GISS political unit data set (CNTRY1X1.1993) contains 186 countries, with 9 of these further subdivided into 168 provinces, states, or regions. Each grid cell was assigned to the spatially dominant political unit, with the exception that small countries and island nations were assigned a grid cell, even when not dominant. Andres et al. (1996) added 15 political units and 10 subdivisions (e.g., Bangladesh and Pakistan were the combined E\&W Pakistan before 1972) that occur in the U.N. energy statistics but not in the original GISS data set. Andres' changes resulted in the CNTYMOD.DAT data file.

The GRIDALL.year files contain most supporting information discussed above, that is, information for each grid cell on the GEIA-id code, the latitude and longitude coordinates of the center of the grid cell, the $\mathrm{CO}_{2}$ emissions, the date-dependent information on the U.N. country-id, the U.N. country name, the NASA-GISS country-id, the NASA-GISS country/state/province-id and the NASA-GISS country/state/province name. The gridded population data were kept as a separate available file. The FORTRAN code READALL.F and the SAS ${ }^{\mathrm{TM}}$ code ALL.SAS are provided to read the GRIDALL.year data files.

Background data sets (Table 7.3) in this database include the POPMOD.DAT data file and for the political unit information the CNTYMOD.DAT data file. Both files are arranged similarly to the GRIDCAR.year data files in that they are arranged sequentially as one record per line in bands starting with grid cells centered at 179.5 degrees West to grid cells centered at 179.5 degrees East, and from grid cells centered at 89.5 degrees North to grid cells centered at 89.5 degrees South ( 64800 lines). The CNTRY1X1.COD file identifies the NASA-GISS country/state or province names and their NASA-GISS-id country/state or province code (355 lines). The GISSUN.COD file translates the NASA-GISS-id country code to the UN-id/UN country name and codes (217 lines).

The remaining background files are the FORTRAN files to read the POPMOD.DAT and CNTYMOD.DAT files (READMOD.F), and the CNTRY1X1.COD and GISSUN.COD files (READCODE.F). Lastly, the FORTRAN program INTEGRAT.F shows how the background files (GRIDCAR.year, CNTYMOD.DAT, CNTRY1X1.COD and GISS UN.COD) were incorporated when combined with the changes over time in the political unit names. Executing the INTEGRAT.F code results in the GRIDALL.year files. The README file comprises this documentation.

Summary data sets (Table 7.4) in this database are (a) an ASCI file of the latitudinal summations of the gridded $\mathrm{CO}_{2}$ emissions for the different years (LAT.TAB) and a graphic representation (LAT.gif) of the same information, and (b) world maps of the gridded $\mathrm{CO}_{2}$ emissions for the different years in gif formats. The AMAP files (AMAP90.gif, AMAP80.gif, AMAP70.gif, AMAP60.gif, and AMAP50.gif) are very similar to the by Andres et al. (1996) published maps, but revised for the Puerto Rico and Unites States emissions (see sections 3 and 5). The AMAP maps are based on $\mathrm{CO}_{2}$ emissions in units of million metric tons $\mathrm{C} /$ year/gridcell. The BMAP maps (BMAP90.gif, BMAP80.gif, BMAP70.gif, BMAP60.gif and BMAP50.gif) are based on $\mathrm{CO}_{2}$ emissions that are standardized for grid cell area $\left(\mathrm{g} \mathrm{C} / \mathrm{year} / \mathrm{m}^{2}\right)$. 


\section{GLOBAL TOTALS, LATITUDINAL DISTRIBUTIONS AND CHANGES OVER TIME IN $\mathrm{CO}_{2}$ EMISSIONS}

Reported estimates of global totals of $\mathrm{CO}_{2}$ emissions and globally summed national $\mathrm{CQ}$ emissions differ (Table 6.1). Boden et al. (1996) present four reasons why the sums of the estimated emissions from all countries (columns 3 and 4, Table 6.1) are not equal to the estimates given for global total emissions (column 2, Table 6.1):

1) Global totals include emissions from bunker fuels whereas these are not included in any national totals. Bunker fuels are fuels consumed by ships and aircraft engaged in international transportation.

2) Global totals include estimates for the oxidation of non-fuel hydrocarbon products whereas national totals do not.

3) Global totals do not include annual changes in fuel stocks whereas annual changes in fuel stocks are included in national totals.

4) There are statistical anomalies in the international statistics: for example, the sum of exports from all exporters is not identical to the sum of imports for all importers.

Table 6.1 $\mathrm{CO}_{2}$ emissions in million metric tons of $\mathrm{C}$ per year

\begin{tabular}{cccc}
\hline YEAR & $\begin{array}{c}\text { Global Totals } \\
\text { NDP030/R6 p24 }\end{array}$ & $\begin{array}{c}\text { Summed National Emissions from } \\
\text { NATIONS92.EMS file from } \\
\text { NDP030/R6 (+Bunkers) }\end{array}$ & $\begin{array}{c}\text { Summed National } \\
\text { Emissions from } \\
\text { Gridded Files }\end{array}$ \\
\hline 1950 & $1638^{\mathrm{a}}$ & $1587(+35)^{\mathrm{a}}$ & $1589^{\mathrm{b}}$ \\
1960 & 2586 & $2505(+65)$ & 2505 \\
1970 & 4084 & $3861(+120)$ & 3861 \\
1980 & 5290 & $5043(+125)$ & 5043 \\
1990 & 6099 & $5811(+115)$ & $5812^{\mathrm{c}}$ \\
\hline
\end{tabular}

With regard to Table 6.1 three more points have to be made. References to the points are marked in the table.

(a) Emissions from bunker fuels are included in the global totals (second column) and are listed within parenthesis under the summed national emissions (third column). The bunkers can be added to the summed national emissions (columns three and four) to compare those with the global totals listed in the second column. Bunker fuel consumption generally accounts for roughly half the difference between the global totals and the sum of the national emissions.

(b) The difference in 1950 for the summed national emissions (columns three and four) is because calculating national emissions for Iran yields negative numbers (export is 1.5 units more than production); this negative number is set to zero in the gridded data file.

(c) The difference in 1990 for the summed national emissions (columns three and four) is because the Netherlands Antilles exported 0.3 units more than production, resulting in a negative value that is incorporated in column three and set to zero in the gridded database. 
Andres et al. (1996) summed the gridded emissions over the latitudinal bands (file 22) and noted changes in the prominent peaks (Fig. 6.1), e.g., the peak at 51.5 degrees North shows a constant increase of 40 million metric tons $C$ per decade up to 1980 , while a decrease of 10 million metric tons occurs between 1980 and 1990. Table 6.2 quantifies the shifts in the peaks over time for the major contributing countries as percent contribution of the $\mathrm{CO}_{2}$ emissions of the summed latitudinal emissions. The figures and tables presented in this database are, however, revised for Puerto Rico's emission, which Andres et al. (1996) based on the U.S. per capita emissions while here it is based on Puerto Rico's U.N. emission estimates (Boden et al., 1996). The emission levels of the 50 states of the United States were revised accordingly.

The latitudinal $\mathrm{CO}_{2}$ emission distribution (Fig. 6.1) shows a continuous slow shift southward towards mid-northern latitudes. The general latitudinal shift is due to different growth rates in emissions in different countries. It does not contain any changes within countries because the within-country population distribution is always based on the 1984 data. Decreasing relative contributions to the summed latitudinal $\mathrm{CO}_{2}$ emissions (Table 6.2) are in general due to the relative slower increase in emissions of certain countries compared to other countries. Actual decreases occur between northern latitudes 54 to 47 (file 22). These actual decreases in $\mathrm{CO}_{2}$ emissions took place between 1980 and 1990 . mainly in Western Europe and Poland, and to a slight degree in Canada. In the Southern Hemisphere the only and very minor decrease (less than $4 \%$ of the latitudinal sum) took place between 13 and 15 degrees South, because of fluctuating Uruguay emissions.

It has to be noted that the changes listed for the latitudinal summations, and the changes for countries, listed in tables 6.3 and 6.4 are dependent on what years the emissions are compared. Differences might be larger or smaller for other 10-year comparisons (see Boden et al., 1996 for yearly national emissions). 


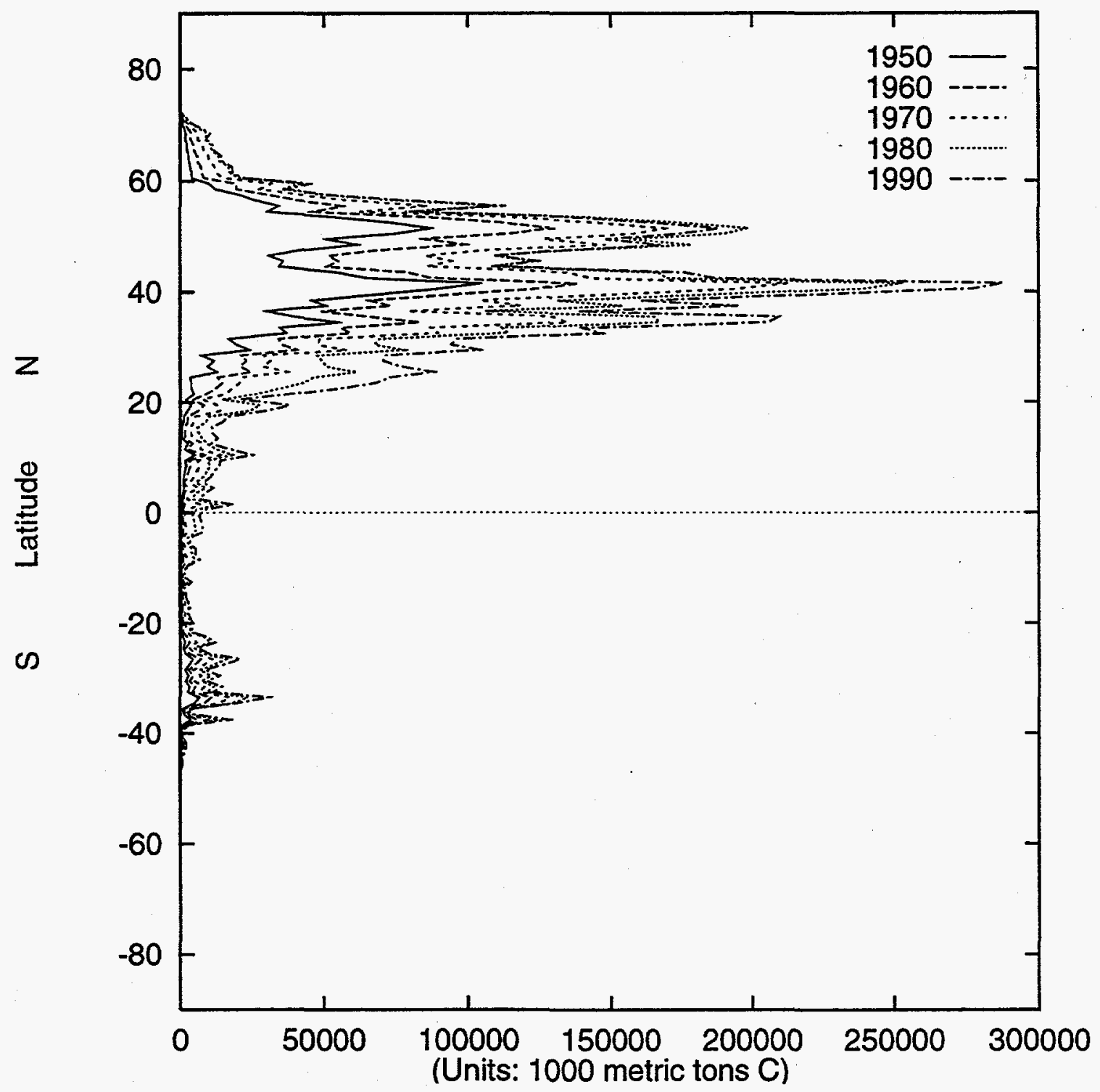

Fig. 6.1. Latitudinal distribution of decadal carbon emisions data: 1950 - 1990 
Table 6.2 Latitudinal emissions in units of thousand metric tons $\mathbf{C}$ per year and the percent contribution by the major $\mathrm{CO}_{2}$ emitting countries relative to the total latitudinal $\mathrm{CO}_{2}$ emissions.

\begin{tabular}{|c|c|c|c|c|c|}
\hline $\begin{array}{l}\text { Latitude/ } \\
\text { countries }\end{array}$ & 1950 & 1960 & 1970 & 1980 & 1990 \\
\hline 51.5 degrees $N$ & 87276 & 129250 & 169181 & 198685 & 188591 \\
\hline U.K. & $39 \%$ & $31 \%$ & $26 \%$ & $20 \%$ & $20 \%$ \\
\hline E. Germany & $18 \%$ & $20 \%$ & $20 \%$ & $18 \%$ & $17 \%$ \\
\hline W. Germany & $13 \%$ & $15 \%$ & $12 \%$ & $11 \%$ & $12 \%$ \\
\hline U.S.S.R. & $11 \%$ & $16 \%$ & $19 \%$ & $24 \%$ & $27 \%$ \\
\hline Poland & $8 \%$ & $10 \%$ & $11 \%$ & $15 \%$ & $12 \%$ \\
\hline 41.5 degrees $N$ & 104848 & 138532 & 212429 & 253227 & 287932 \\
\hline U.S.A. & $88 \%$ & $77 \%$ & $73 \%$ & $65 \%$ & $61 \%$ \\
\hline U.S.S.R. & $7 \%$ & $9 \%$ & $10 \%$ & $12 \%$ & $11 \%$ \\
\hline China & $1 \%$ & $5 \%$ & $4 \%$ & $6 \%$ & $8 \%$ \\
\hline 34.5 degrees $N$ & 55068 & 83560 & 135136 & 167200 & 205633 \\
\hline U.S.A. & $87 \%$ & $66 \%$ & $59 \%$ & $51 \%$ & $44 \%$ \\
\hline Japan & $8 \%$ & $13 \%$ & $25 \%$ & $24 \%$ & $23 \%$ \\
\hline China & $3 \%$ & $18 \%$ & $11 \%$ & $17 \%$ & $22 \%$ \\
\hline 25.5 degrees $N$ & 12673 & 24652 & 37188 & 61846 & 88474 \\
\hline U.S.A. & $70 \%$ & $41 \%$ & $40 \%$ & $25 \%$ & $19 \%$ \\
\hline India & $11 \%$ & $10 \%$ & $11 \%$ & $12 \%$ & $16 \%$ \\
\hline China & $7 \%$ & $36 \%$ & $24 \%$ & $27 \%$ & $31 \%$ \\
\hline Mexico & $5 \%$ & $6 \%$ & $6 \%$ & $9 \%$ & $8 \%$ \\
\hline 18.5 degrees $N$ & 2395 & 6152 & 13973 & 24305 & 30166 \\
\hline India & $36 \%$ & $25 \%$ & $18 \%$ & $18 \%$ & $29 \%$ \\
\hline Puerto Rico & $28 \%$ & $32 \%$ & $23 \%$ & $16 \%$ & $11 \%$ \\
\hline Mexico & $21 \%$ & $17 \%$ & $12 \%$ & $17 \%$ & $17 \%$ \\
\hline U.S. Virg.Isl. & $0 \%$ & $1 \%$ & $19 \%$ & $17 \%$ & $7 \%$ \\
\hline 10.5 degrees $N$ & 5291 & 8390 & 13909 & 18078 & 25188 \\
\hline Venezuela & $81 \%$ & $77 \%$ & $65 \%$ & $56 \%$ & $51 \%$ \\
\hline India & $10 \%$ & $11 \%$ & $11 \%$ & $15 \%$ & $21 \%$ \\
\hline Nigeria & $1 \%$ & $1 \%$ & $5 \%$ & $12 \%$ & $11 \%$ \\
\hline 33.5 degrees $\mathrm{S}$ & 6636 & 10702 & 17228 & 23607 & 30883 \\
\hline Australia & $51 \%$ & $51 \%$ & $51 \%$ & $53 \%$ & $53 \%$ \\
\hline South Africa & $30 \%$ & $30 \%$ & $29 \%$ & $30 \%$ & $31 \%$ \\
\hline Chile & $14 \%$ & $14 \%$ & $16 \%$ & $13 \%$ & $13 \%$ \\
\hline
\end{tabular}


Changes from 1980 to 1990 in total emissions of the top emitting countries are listed in Table 6.3. In addition, the increase as percent from 1980 emissions over 10 years are listed as are net per capita changes. The per capita values are obtained from Boden et al. (1996) and can not be calculated from this database. Boden et al. (1996) used annual population data provided by the United Nations, not the 1984 population database.

Table 6.3 Changes in fossil-fuel $\mathrm{CO}_{2}$ emissions from 1980 to 1990 in the top emitting countries

\begin{tabular}{lccc}
\hline Country & $\begin{array}{c}\text { Emission increase in } \\
\text { 1000 metric C per year } \\
\text { from 1980 to 1990 }\end{array}$ & $\begin{array}{c}\text { \% increase from 1980 } \\
\text { to 1990 per year }\end{array}$ & $\begin{array}{c}\text { Per capita change in } \\
\text { metric tons C from 1980 } \\
\text { to 1990 per year }\end{array}$ \\
\hline China & 254297 & $63 \%$ & +0.16 \\
India & 90640 & $95 \%$ & +0.08 \\
U.S.S.R. & 89982 & $10 \%$ & +0.02 \\
U.S.A. & 85915 & $7 \%$ & -0.13 \\
Japan & 40683 & $16 \%$ & +0.21 \\
\hline
\end{tabular}

Major emission changes between the years 1980 and 1990 in other countries are listed in Table 6.4. These listings, ordered according to the magnitude of total change, might aid in the interpretation of the latitudinal emission distribution, and in changes that occur in the mapped emissions.

Andres et al. (1996) published maps of the gridded fossil-fuel emission rates in units of million tons $C$ per grid cell per year. These maps, corrected for the Puerto Rico and U.S.A emissions, are available in this database (Table 7: AMAP**. gif) as are maps based on log transformed emission rates that are standardized for grid cell area $\left[\log \left(\mathrm{g} \mathrm{C}^{2} \mathrm{~m}^{2}\right)\right.$; BMAP*.*.gif $]$. Grid cell surface areas for those maps were calculated based on latitude following NASA-GISS' grid cell calculations. Because of the differences in processing and the selection of scale break-points and colors, differences over time in the maps are visualized somewhat differently. For example, a greater visual differentiation in emissions in the Southern Hemisphere occurs at the cost of less visual differentiation in emissions in the Northern Hemisphere in the second set of maps. 
Table 6.4 Major changes in fossil-fuel emissions from 1980 to 1990 in other countries

\begin{tabular}{lcc}
\hline Country & $\begin{array}{c}\text { Change in emissions in 1000 } \\
\text { metric tons C per year from } \\
\mathbf{1 9 8 0} \text { to } 1990\end{array}$ & $\begin{array}{c}\text { \% change from 1980 to } \\
\mathbf{1 9 9 0}\end{array}$ \\
\hline Dem. P. Rep. of Korea & +32847 & $+96 \%$ \\
Republic of Korea & +31683 & $+92 \%$ \\
Iran & +26125 & $+82 \%$ \\
South Africa & +21062 & $+36 \%$ \\
Turkey & +18939 & $+91 \%$ \\
Australia & +17260 & $+31 \%$ \\
Indonesia & +16574 & $+64 \%$ \\
Thailand & +15058 & $+138 \%$ \\
Mexico & +15910 & $+23 \%$ \\
\hline France & -35527 & $-27 \%$ \\
Poland & -30252 & $-24 \%$ \\
Federal Rep. Germany & -23952 & $-12 \%$ \\
Romania & -9920 & $-19 \%$ \\
Czechoslovakia & -8458 & $-13 \%$ \\
Belgium & -8150 & $-23 \%$ \\
Sweden & -5857 & $-30 \%$ \\
U.K. & -5085 & $-3 \%$ \\
Hungary & -4486 & $-20 \%$ \\
Netherlands & -3669 & $-9 \%$ \\
Denmark & -3335 & $-19 \%$ \\
Canada & -3239 & $-3 \%$ \\
\hline
\end{tabular}




\section{FILE DESCRIPTIONS}

This section describes the content and format of each of the 33 files comprising this NDP (Tables 7.1, 7.2, 7.3 and 7.4). File names and a brief description of the files are given.

\subsection{GRIDDED $\mathrm{CO}_{2}$ EMISSIONS}

The five single-field GRIDCAR.year data files are the '1992 UN revision' (U.N., 1994) data of fossil-fuel $\mathrm{CO}_{2}$ emissions ( 1000 metric tons $\mathrm{C} /$ one* $^{*}$ one degree grid cell/year) arranged sequentially as one record per line in bands starting with grid cells centered at 179.5 degrees West to grid cells centered at 179.5 degrees East, and from grid cells centered at 89.5 degrees North to grid cells centered at 89.5 degrees South.

The FORTRAN 77 code (READGRID.F) is provided to read the GRIDCAR.year data files.

Table 7.1 Single-field $\mathrm{CO}_{2}$ emission file names, sizes, types and format

\begin{tabular}{|c|c|c|c|}
\hline File names and description & $\begin{array}{c}\text { File size } \\
\text { (bytes) }\end{array}$ & data type & format \\
\hline $\begin{array}{l}\text { 1. GRIDCAR.90 } \\
1990 \mathrm{CO}_{2} \text { emissions estimates for one } \\
\text { degree by one degree grid cells } \\
\text { (thousand metric tons } \mathrm{C} \text { per year) }\end{array}$ & 1231200 & real & f18.6 \\
\hline $\begin{array}{l}\text { 2. GRIDCAR. } 80 \\
1980 \mathrm{CO}_{2} \text { emissions estimates } \\
\text { (thousand metric tons } \mathrm{C} \text { per year) }\end{array}$ & 1231200 & real & f18.6 \\
\hline $\begin{array}{l}\text { 3. GRIDCAR. } 70 \\
1970 \mathrm{CO}_{2} \text { emissions estimates } \\
\text { (thousand metric tons } \mathrm{C} \text { per year) }\end{array}$ & 1231200 & real & f18.6 \\
\hline $\begin{array}{l}\text { 4. GRIDCAR. } 60 \\
1960 \mathrm{CO}_{2} \text { emissions estimates } \\
\text { (thousand metric tons } \mathrm{C} \text { per year) }\end{array}$ & 1231200 & real & f18.6 \\
\hline $\begin{array}{l}\text { 5. GRIDCAR.50 } \\
1950 \mathrm{CO}_{2} \text { emissions estimates } \\
\text { (thousand metric tons } \mathrm{C} \text { per year) }\end{array}$ & 1231200 & real & $\mathrm{f} 18.6$ \\
\hline $\begin{array}{l}\text { 6. READGRID.F } \\
\text { FORTRAN } 77 \text { code to read files } 1 \text { through } 5\end{array}$ & 1902 & & \\
\hline
\end{tabular}




\subsection{GRID CELL INFORMATION ON $\mathrm{CO}_{2}$ EMISSION, LOCATION AND POLITICAL UNIT}

The five nine-field GRIDALL.year data files, provide the same information on the $\mathrm{CO}_{2}$ emissions due to fossil-fuel burning, gas flaring and cement production as the GRIDCAR files, but also information on the grid cell with regard to the latitude and longitude coordinates, the GEIA-id code, the UN-id and accompanying country name, and the NASA-GISS country and political unit codes and name.

The FORTRAN 77 code (READALL.F) and SAS ${ }^{\text {TM }}$ code (ALL.SAS) are provided to read the GRIDALL files.

Table 7.2 Nine-field $\mathrm{CO}_{2}$ emission file names, sizes, types and format

\begin{tabular}{|c|c|c|c|}
\hline File names and description & $\begin{array}{c}\text { File size } \\
\text { (bytes) }\end{array}$ & data type & format \\
\hline 7. GRIDALL.90 & 7646400 & & \\
\hline \multicolumn{4}{|l|}{$\begin{array}{l}\text { Files } 7 \text { through } 11 \text { contain the following } \\
\text { information for each grid cell: }\end{array}$} \\
\hline GEIA-cell-id & & character & a6 \\
\hline latitude (degrees) & & real & f6.1 \\
\hline longitude (degrees) & & real & f6.1 \\
\hline $\mathrm{CO}_{2}$ emissions ( 1000 metric tons $\mathrm{C}$ per year) & & real & $\mathrm{g} 12.6$ \\
\hline \multicolumn{4}{|l|}{ and date-dependent information: } \\
\hline U.N. country-id & & integer & i3 \\
\hline U.N. country name & & character & $\mathrm{a} 40$ \\
\hline NASA-GISS country-id & & integer & i6 \\
\hline NASA-GISS country/state, province-id & & integer & i6 \\
\hline NASA-GISS country/state, province name & & character & a14 \\
\hline
\end{tabular}

8. GRIDALL.80

7646400

Same content as file 7, except 1980 data

9. GRIDALL.70

7646400

Same content as file 7, except 1970 data

10. GRIDALL.60

7646400

Same content as file 7, except 1960 data

11. GRIDALL.50

7646400

Same content as file 7 , except 1950 data

12. READALL.F

FORTRAN code to read files 7 through 11

13. ALL.SAS ${ }^{1}$

2770

SAS ${ }^{\mathrm{TM}}$ code to process files 7 through 11

${ }^{1} \mathrm{SAS}^{\mathrm{TM}}$ is a registered trademark of the SAS institute, Inc., Cary, North Carolina 27511-8000. 


\subsection{UNDERLYING DATABASES AND CODES TO CREATE THE EXTENDED GRIDDED $\mathrm{CO}_{2}$ EMISSION FILES}

Table 7.3 lists the files and information used to create the GRIDALL.year files from the GRIDCAR.year files. The FORTRAN 77 code INTEGRAT.F uses the GRIDCAR.year files, the CNTYMOD.DAT, the CNTRY1X1.COD and the GISSUN.COD as input and generates the GRIDALL.year files. The POPMOD.DAT and CNTYMOD.DAT files can be read by the READMOD.F FORTRAN 77 code; the CNTRY1X1.COD and GISSUN.COD files can be read by the READCODE.F FORTRAN 77 code. The README file is very similar to this document.

Table 7.3 Background file names, sizes, types and format

\begin{tabular}{|c|c|c|c|}
\hline File names and description & $\begin{array}{l}\text { File size } \\
\text { (bytes) }\end{array}$ & data type & format \\
\hline $\begin{array}{l}\text { 14. POPMOD.DAT } \\
\text { The } 1984 \text { population per grid cell }\end{array}$ & 712800 & integer & $\mathrm{i} 10$ \\
\hline $\begin{array}{l}\text { 15. CNTYMOD.DAT } \\
\text { NASA-GISS country/state,province-id }\end{array}$ & 453600 & integer & $i 6$ \\
\hline $\begin{array}{l}\text { 16. CNTRY1X1.COD } \\
\text { NASA-GISS country-id and country/state,province-id } \\
\text { NASA-GISS country and country/state,province name }\end{array}$ & 28755 & $\begin{array}{l}\text { integer } \\
\text { character }\end{array}$ & $\begin{array}{l}\text { i6 } \\
\text { a14 }\end{array}$ \\
\hline $\begin{array}{l}\text { 17. GISSUN.COD } \\
\text { UN-id } \\
\text { NASA-GISS country-id } \\
\text { UN country name }\end{array}$ & 13888 & $\begin{array}{l}\text { integer } \\
\text { integer } \\
\text { character }\end{array}$ & $\begin{array}{l}\text { i3 } \\
\text { i6 } \\
\text { a42 }\end{array}$ \\
\hline $\begin{array}{l}\text { 18. READMOD.F } \\
\text { FORTRAN code to read files } 14 \text { and } 15\end{array}$ & 569 & & \\
\hline $\begin{array}{l}\text { 19. READCODE.F } \\
\text { FORTRAN code to read files } 16 \text { and } 17\end{array}$ & 968 & & \\
\hline $\begin{array}{l}\text { 20. INTEGRAT.F } \\
\text { FORTRAN } 77 \text { code to integrate background files }\end{array}$ & 14171 & & \\
\hline $\begin{array}{l}\text { 21. } \text { README }=\text { ndp058.doc } \\
\text { This document }\end{array}$ & & & \\
\hline
\end{tabular}




\subsection{LATITUDINAL SUMMARY AND MAPS}

Table 7.4 lists the summary files in this database. The LAT.TAB is an ASCII file with the summed fossil-fuel emissions for 1950, 1960,1970, 1980 and 1990 of each latitudinal band (thousand metric tons $\mathrm{C}$ /year/latitudinal band). The LAT.gif file is a visual representation of the same information. The AMAP90.gif, AMAP80.gif, AMAP70.gif, AMAP60.gif and AMAP50.gif files are Andres et al.'s (1996) gridded fossil-fuel $\mathrm{CO}_{2}$ emission maps (million metric tons C/year/grid cell); the BMAP90.gif, BMAP80.gif, BMAP70.gif, BMAP60.gif and BMAP50.gif files are the $\log$ transformed, standardized for grid cell area emission rate maps $(\log (\mathrm{C}$ emission/year/unit area $)$ ) which after transformation are expressed in units of grams $\mathrm{C}$ per square meter $\left(\mathrm{g} \mathrm{C} / \mathrm{year} / \mathrm{m}^{2}\right)$.

Table 7.4 Summary file names, sizes and types

\begin{tabular}{|c|c|c|}
\hline Fïle names and description & $\begin{array}{c}\text { File size } \\
\text { (bytes) }\end{array}$ & File Type \\
\hline $\begin{array}{l}\text { 22. LAT.TAB } \\
\text { (thousand metric tons C/latitudinal band/yr) }\end{array}$ & 11235 & ASCII \\
\hline $\begin{array}{l}\text { 23. LAT.gif } \\
\text { (thousand metric tons C/latitudinal band/yr) }\end{array}$ & 17827 & gif \\
\hline $\begin{array}{l}\text { 24. AMAP90.gif } \\
1990 \text { world map of gridded } \mathrm{CO}_{2} \text { emissions } \\
\text { (million metric tons } \mathrm{C} / \text { grid cell/yr) }\end{array}$ & 19548 & gif \\
\hline $\begin{array}{l}\text { 25. AMAP80.gif } \\
1980 \text { world map (million metric tons C/grid cell/yr) }\end{array}$ & 19534 & gif \\
\hline $\begin{array}{l}\text { 26. AMAP70.gif } \\
1970 \text { world map (million metric tons C/grid cell/yr) }\end{array}$ & 19198 & gif \\
\hline $\begin{array}{l}\text { 27. AMAP60.gif } \\
1960 \text { world map (million metric tons C/grid cell/yr) }\end{array}$ & 18328 & gif \\
\hline $\begin{array}{l}\text { 28. AMAP50.gif } \\
1950 \text { world map (million metric tons } \mathrm{C} / \text { grid cell/yr) }\end{array}$ & 17378 & gif \\
\hline $\begin{array}{l}\text { 29. BMAP90.gif } \\
1990 \text { world map of gridded } \mathrm{CO}_{2} \text { emissions } \\
\text { ( } \log \text { (C/unit area) } \gg>\mathrm{g} \mathrm{C}^{2} / \mathrm{mr} \text { ) }\end{array}$ & 16804 & gif \\
\hline $\begin{array}{l}\text { 30. BMAP80.gif } \\
\left.1980 \text { world map (log (C/unit area) } \gg \mathrm{g} \mathrm{C} / \mathrm{m}^{2} / \mathrm{yr}\right)\end{array}$ & 16614 & gif \\
\hline $\begin{array}{l}\text { 31. BMAP70.gif } \\
1970 \text { world map (log (C/unit area) }>>g \text { C/m²/yr) }\end{array}$ & 16735 & gif \\
\hline $\begin{array}{l}\text { 32. BMAP60.gif } \\
\left.1960 \text { world map (log (C/unit area) }>>g ~ C / \mathrm{m}^{2} / \mathrm{yr}\right)\end{array}$ & 16671 & gif \\
\hline $\begin{array}{l}\text { 33. BMAP50.gif } \\
\left.1950 \text { world map (log (C/unit area) }>>g ~ C / m^{2} / y r\right)\end{array}$ & 16700 & gif \\
\hline
\end{tabular}


Table 7.5 summarizes the number of countries and political units involved in the database and the number of countries and political units without information on $\mathrm{CO}_{2}$ emissions, e.g., Namibia and Lesotho.

Table 7.5 Overview of number of countries and political units involved

\begin{tabular}{lcc}
\hline & $\begin{array}{c}\text { \# of countries identified with a UN-id } \\
\text { (\# without } \mathrm{CO}_{2} \text { emissions) }\end{array}$ & $\begin{array}{c}\text { \# of political units identified } \\
\text { with a NASA-GISS-id } \\
\text { (\# without } \mathrm{CO}_{2} \text { emissions) }\end{array}$ \\
\hline 1950 & $180(28)$ & $334(33)$ \\
1960 & $196(16)$ & $360(21)$ \\
1970 & $196(5)$ & $359(10)$ \\
1980 & $195(3)$ & $358(8)$ \\
1990 & $196(4)$ & $360(8)$ \\
\hline
\end{tabular}

\section{CDIAC QUALITY ASSURANCE CHECKS}

An important part of the data packaging process at CDIAC involves the quality assurance (QA) of data before distribution. To guarantee data of the highest possible quality, CDIAC performs extensive QA checks, examining the data for completeness, reasonableness, and accuracy.

However, QA on the national $\mathrm{CO}_{2}$ emissions had been performed by CDIAC (NDP030/R6) prior to processing these emissions as a gridded database. The following data checks were specifically performed for NDP058:

1) National totals were compared to reported global totals:

(a) Grid cell values of fossil-fuel emissions were summed by country name in SAS ${ }^{\mathrm{TM}}$ and the resulting national emissions were compared to a previously published database of national emissions (NDP030/R6). Summed gridded national totals check out exactly with NDP030/R6's national totals, but:

(b) Andres et al. (1996) allocated to Puerto Rico a population-based fraction of the total US emissions (UN code 840) (i.e., C emissions of 18,786 thousand metric tons for 1990), while the national emissions in NDP030/R6 had for Puerto Rico (UN code 630) a separately calculated emission of $~ 6$-fold less than the population based fraction (i.e., 3193 thousand metric tons for 1990). This population based fraction, allocated to Puerto Rico, was in the NDP030/R6 appropriately allocated to the 50 states of the U.S.A. (total of $1,322,212$ thousand metric tons for 1990). This has now been corrected, based on the NDP030/R6 data, for each of gridded database files.

(c) The national total emissions reported in NDP030/R6 had failed to replace UN code 887 by UN code 886 for 1990's cement production (113 thousand metric tons C per year (Yemen). Democratic Yemen (UN code 720) and Yemen (UN code 886) merged on 22 May, 1990 to form a single state (UN code 887). For 1990, the separation between Democratic Yemen and former Yemen should have been maintained for all emissions and UN code 887 should not have been in the database. Therefore, the 1990 cement emission allocation of Yemen was not incorporated in the gridded database of Andres et al.(1996). This has now been corrected. 
2) Converting negative emission values to zero:

Fossil fuel emissions for Iran for 1950 and for the Netherlands Antilles for 1990 were set to zero. Negative emissions were calculated and reported for these two instances in NDP030/R6 because exports of fossil fuels were larger than the sum of gross production and imports.

3) Bunker Summations:

An additional QA was performed on the NDP30/R6 while collecting information for Table 6.1. Due to SAS ${ }^{\mathrm{TM}}$ not performing any calculations when missing values occur as any of the elements in an equation, the summation of bunkers could not be performed correctly using the SAS ${ }^{\mathrm{TM}}$ program in the NDP030/R6. Replacement of missing values by zeros has corrected this potential error in using the NDP030/R6 database.

\section{HOW TO OBTAIN THE DATABASE AND DOCUMENTATION}

This database (NDP058) and the related NDP030/R6 database are available free of charge from CDIAC. The files are available from CDIAC's anonymous FTP (file transfer protocol) area via the Internet. Obtaining the data from CDIAC's anonymous FTP area requires a computer with FTP software and access to the Internet. Commands used to obtain the database are shown below. For additional information, contact CDIAC.

$>$ ftp cdiac.esd.ornl.gov (or >ftp 128.219.24.36)

Login: anonymous

Password: YOU@your internet address

Guest login ok, access restrictions apply.

$\mathrm{ftp}>\mathrm{cd}$ pub/ndp058

$\mathrm{ftp}>$ dir

ftp $>$ mget files

$\mathrm{ftp}>$ quit

Uncompress files on workstation, if obtained in compressed format.

CDIAC's World Wide Web home page's address: http://cdiac.esd.ornl.gov

For non-FTP data acquisitions (e.g., IBM- or MacIntosh-formatted floppy diskettes; 8200 or 8500 format 8-mm tape), users may request data from CDIAC using the following information:

Address: Carbon Dioxide Information Analysis Center

Oak Ridge National Laboratory

P.O. Box 2008

Oak Ridge, Tennessee 37831-6335, U.S.A.

Telephone: (423) 574-3645 (Voice)

(423) 574-2232 (FAX)

Electronic mail: cdiac@ornl.gov

All GEIA information is available through anonymous FTP:

$>$ ftp ncardata.ucar.edu

$\mathrm{ftp}>\mathrm{cd}$ pub/GEIA

All NASA-GISS referenced information is available through anonymous FTP:

$>$ ftp nasagiss.giss.nasa.gov

or http://www.giss.nasa.gov 


\section{REFERENCES}

Andres, R.J., G. Marland, I. Fung, and E. Matthews. 1996. A one degree by one degree distribution of carbon dioxide emissions from fossil-fuel consumption and cement manufacture, 1950-1990. Global Biogeochemical Cycles 10:3:419-429

Boden, T.A., G. Marland, and R.J. Andres, 1996. Estimates of global, regional, and national annual $\mathrm{CO}_{2}$ emissions from fossil-fuel burning, hydraulic cement production, and gas flaring: 1950-1992, Rep. ORNL/CDIAC-90. NDP-030/R6, 600 pp., Oak Ridge Nat. Lab., Oak Ridge, Tenn.

Boden, T.A., D.P. Kaiser, R.J. Sepanski and F.W. Stoss, 1994. Trends '93, A Compendium of Data on Global Change. Carbon Dioxide Information Analysis Center, World Data Center-A for Atmospheric Trace Gases. Environmental Sciences Division, Oak Ridge National Laboratory, Oak Ridge, Tenn. 37831-6335.

Broecker, W.S. et al., 1986. Isotopic versus micrometeorological ocean $\mathrm{CO}_{2}$ fluxes: A serious conflict. J. Geophys. Res. 91:10517-10527.

Fung, I., C.J. Tucker and K.C. Prentice, 1987. Application of AVHRR vegetation index to study atmosphere-biosphere exchange of $\mathrm{CO}_{2}$. J. Geophys. Res. 92:2999-3015.

Houghton, R.A. et al., 1987. The flux of carbon from terrestrial ecosystems to the atmosphere in 1980 due to changes in land use: geographic distribution of global flux. Tellus 39B:122-139.

Keeling, C.D., 1973. Industrial production of carbon dioxide from fossil-fuels and limestone. Tellus 25:174-198.

Lemer, J., E. Matthews and I. Fung, 1988. Methane emissions from animals: A global high-resolution database. Global Biochemical Cycles, 2:139-156.

Marland, G., and R.M. Rotty, 1984. Carbon dioxide emissions from fossil-fuels: A procedure for estimation and results for 1950-1982. Tellus 36(B):232-261.

Marland, G, R.M. Rotty and N.L. Treat, 1985. $\mathrm{CO}_{2}$ from fossil fuel burning: Global distribution of emissions. Tellus 37(B):243-258.

Matthews, E. 1983. Global vegetation and land use: New high-resolution data bases for climate studies. I. Clim. Appl. Meteorol., 22:474-487.

Solomon, C., 1993. Cement. In Cement Minerals Yearbook-1992. U.S. Department of Interior, Bureau of Mines, Washington, D.C.

United Nations, 1994. 1992 Energy Statistics Yearbook. United Nations Statistical Division (UNSTAT), 2 United Nations Plaza, New York. N.Y. 10017 
APPENDICES 
APPENDIX A

A.1 LAT.TAB

YEARLY LATITUDINAL SUMMATIONS OF $\mathrm{CO}_{2}$ EMISSIONS

(thousand metric tons $\mathrm{C} / \mathrm{year} / \mathrm{latitidinal}$ band)

\begin{tabular}{|c|c|c|c|c|c|}
\hline $\begin{array}{l}\text { Midpoint of } \\
\text { one degree } \\
\text { latitude bands }\end{array}$ & 1950 & 1960 & 1970 & 1980 & 1990 \\
\hline 89.5 & 0.0 & 0.0 & 0.0 & 0.0 & 0.0 \\
\hline 88.5 & 0.0 & 0.0 & 0.0 & 0.0 & 0.0 \\
\hline 87.5 & 0.0 & 0.0 & 0.0 & 0.0 & 0.0 \\
\hline 86.5 & 0.0 & 0.0 & 0.0 & 0.0 & 0.0 \\
\hline 85.5 & 0.0 & 0.0 & 0.0 & 0.0 & 0.0 \\
\hline 84.5 & 0.0 & 0.0 & 0.0 & 0.0 & 0.0 \\
\hline 83.5 & 0.0 & 0.0 & 0.0 & 0.0 & 0.0 \\
\hline 82.5 & 0.0 & 0.0 & 0.0 & 0.0 & 0.0 \\
\hline 81.5 & 0.0 & 0.0 & 0.0 & 0.0 & 0.0 \\
\hline 80.5 & 0.0 & 0.0 & 0.0 & 0.0 & 0.0 \\
\hline 79.5 & 0.0 & 0.0 & 0.0 & 0.0 & 0.0 \\
\hline 78.5 & 0.0 & 0.0 & 0.0 & 0.0 & 0.0 \\
\hline 77.5 & 0.0 & 0.0 & 0.0 & 0.0 & 0.0 \\
\hline 76.5 & 0.0 & 0.0 & 0.0 & 0.0 & 0.0 \\
\hline 75.5 & 0.0 & 0.0 & 0.0 & 0.0 & 0.0 \\
\hline 74.5 & 0.0 & 0.0 & 0.0 & 0.0 & 0.0 \\
\hline 73.5 & 72.6 & 154.8 & 245.6 & 360.9 & 369.0 \\
\hline 72.5 & 0.0 & 0.0 & 0.0 & 0.0 & 0.0 \\
\hline 71.5 & 324.6 & 691.9 & 1097.6 & 1612.6 & 1769.8 \\
\hline 70.5 & 634.4 & 1272.9 & 2067.7 & 3062.5 & 3461.7 \\
\hline 69.5 & 1232.7 & 2523.7 & 4064.3 & 5999.8 & 6710.8 \\
\hline 68.5 & 1851.8 & 3872.1 & 6309.4 & 9252.4 & 10168.3 \\
\hline 67.5 & 1700.9 & 3514.8 & 5890.1 & 8170.7 & 8679.7 \\
\hline 66.5 & 2156.4 & 4452.4 & 7457.3 & 10325.4 & 10958.2 \\
\hline 65.5 & 2305.9 & 4695.4 & 7809.4 & 10768.3 & 11392.1 \\
\hline 64.5 & 2810.2 & 5686.0 & 9473.4 & 13076.9 & 13941.7 \\
\hline 63.5 & 2850.7 & 5761.2 & 9815.8 & 13390.5 & 14213.1 \\
\hline 62.5 & 3344.5 & 6863.1 & 11750.3 & 16411.2 & 17551.4 \\
\hline 61.5 & 3732.9 & 7114.5 & 12099.8 & 16724.7 & 17927.2 \\
\hline 60.5 & 3843.9 & 7890.7 & 14416.0 & 20209.1 & 21308.5 \\
\hline 59.5 & 9601.3 & 19059.9 & 31564.5 & 42186.7 & 44991.8 \\
\hline 58.5 & 11956.6 & 19235.0 & 27548.1 & 35043.2 & 37135.6 \\
\hline 57.5 & 20051.0 & 30277.5 & 41635.3 & 49995.9 & 51865.6 \\
\hline 56.5 & 25698.5 & 40471.0 & 58826.1 & 73909.6 & 76868.0 \\
\hline 55.5 & 34194.1 & 56716.8 & 86041.0 & 109147.2 & 113091.0 \\
\hline 54.5 & 30400.6 & 46139.8 & 62820.0 & 78571.7 & 80484.6 \\
\hline 53.5 & 53736.6 & 84644.7 & 114385.7 & 141898.4 & 136380.1 \\
\hline 52.5 & 73633.6 & 111701.3 & 145914.3 & 174822.6 & 165301.6 \\
\hline 51.5 & 87276.2 & 129250.2 & 169180.8 & 198685.4 & 188591.0 \\
\hline 50.5 & 75208.4 & 114657.2 & 158072.5 & 190278.5 & 174168.8 \\
\hline
\end{tabular}




\begin{tabular}{|c|c|c|c|c|c|}
\hline 49.5 & 51141.5 & 85029.9 & 126823.7 & 156877.7 & 148367.7 \\
\hline 48.5 & 62088.9 & 98952.0 & 148222.1 & 178658.6 & 167965.2 \\
\hline 47.5 & 42088.3 & 69441.5 & 107265.0 & 134529.0 & 133514.3 \\
\hline 46.5 & 30933.9 & 51773.5 & 85462.0 & 109076.7 & 110051.4 \\
\hline 45.5 & 35769.3 & 55286.8 & 94250.3 & 122206.6 & 124609.2 \\
\hline 44.5 & 34427.6 & 51030.9 & 86036.9 & 108371.0 & 110492.4 \\
\hline 43.5 & 55050.4 & 79396.5 & 135387.0 & 166924.1 & 176423.2 \\
\hline 42.5 & 65207.2 & 87269.2 & 143351.5 & 169720.3 & 186810.7 \\
\hline 41.5 & 104848.2 & 138531.8 & 212428.66 & 253227.2 & 287932.4 \\
\hline 40.5 & 89733.6 & 123853.4 & 194499.3 & 238637.1 & 277166.9 \\
\hline 39.5 & 67138.2 & 93719.4 & 147306.9 & 182302.3 & 217777.0 \\
\hline 38.5 & 45914.4 & 65893.6 & 104270.1 & 131578.3 & 160987.7 \\
\hline 37.5 & 50945.6 & 73568.8 & 118396.8 & 154278.9 & 194883.1 \\
\hline 36.5 & 29913.3 & 49146.8 & 79402.2 & 106304.0 & 138671.9 \\
\hline 35.5 & 39478.8 & 65537.3 & 130015.7 & 165641.3 & 209520.1 \\
\hline 34.5 & 55068.2 & 83560.1 & 135136.1 & 167200.7 & 205632.9 \\
\hline 33.5 & 34690.7 & 56025.1 & 87177.8 & 1118216.6 & 140515.8 \\
\hline 32.5 & 36952.2 & 59721.4 & 89732.3 & 114012.2 & 147067.7 \\
\hline 31.5 & 16619.9 & 34177.4 & 48430.2 & 69412.7 & 96443.9 \\
\hline 30.5 & 19326.4 & 35370.2 & 47930.0 & 67877.8 & 94242.7 \\
\hline 29.5 & 24079.2 & 40690.0 & 58372.9 & 78178.2 & 104013.8 \\
\hline 28.5 & 7156.7 & 20886.8 & 29060.8 & 47706.4 & 71359.2 \\
\hline 27.5 & 11586.5 & 22810.8 & 31360.4 & 49263.8 & 70851.9 \\
\hline 26.5 & 9272.1 & 20600.6 & 28661.6 & 50994.5 & 77169.3 \\
\hline 25.5 & 12673.8 & 24652.1 & 37187.7 & 61846.0 & 88474.2 \\
\hline 24.5 & 3378.3 & 12840.0 & 21077.2 & 46340.2 & 73221.9 \\
\hline 23.5 & 3755.7 & 14331.2 & 20367.0 & 42975.1 & 68043.4 \\
\hline 22.5 & 3803.8 & 12011.9 & 17551.1 & 34430.2 & 54710.8 \\
\hline 21.5 & 4683.4 & 8696.6 & 15464.3 & 26859.8 & 38673.6 \\
\hline 20.5 & 2074.7 & 4455.0 & 7460.0 & 14506.0 & 20595.4 \\
\hline 19.5 & 3718.7 & 7908.0 & 12823.9 & 27634.7 & 38136.5 \\
\hline 18.5 & 2394.5 & 6151.8 & 13972.6 & 24304.8 & 30166.5 \\
\hline 17.5 & 1211.5 & 2628.6 & 5033.2 & 9718.4 & 16189.6 \\
\hline 16.5 & 1075.2 & 2491.3 & 4695.2 & 8642.0 & 14580.8 \\
\hline 15.5 & 702.5 & 1628.2 & 3590.6 & 5986.7 & 10804.3 \\
\hline 14.5 & 690.8 & 1651.1 & 3753.3 & 6261.3 & 10967.3 \\
\hline 13.5 & 726.5 & 1630.8 & 4167.5 & 7430.7 & 12961.6 \\
\hline 12.5 & 2678.0 & 4270.6 & 7666.2 & 9068.4 & 10587.2 \\
\hline 11.5 & 1598.3 & 2459.3 & 6774.6 & 12296.7 & 16820.7 \\
\hline 10.5 & 5291.2 & 8389.6 & 13909.5 & 18078.3 & 25188.5 \\
\hline 9.5 & 1977.1 & 3293.5 & 6131.5 & 9611.3 & 13987.3 \\
\hline 8.5 & 2228.4 & 3709.5 & 6770.5 & 10301.1 & 13678.8 \\
\hline 7.5 & 1710.6 & 2912.1 & 5858.4 & 9192.3 & 11758.3 \\
\hline 6.5 & 1410.6 & 2392.6 & 4923.7 & 7849.7 & 10585.8 \\
\hline 5.5 & 1040.3 & 2477.2 & 3433.7 & 5575.3 & 7916.0 \\
\hline 4.5 & 1521.5 & 2477.2 & 6484.6 & 8740.8 & 11508.9 \\
\hline 3.5 & 954.3 & 1582.7 & 3012.9 & 5345.2 & 8359.9 \\
\hline 2.5 & 818.2 & 1411.6 & 2540.3 & 4399.3 & 6683.5 \\
\hline 1.5 & 1037.5 & 1645.2 & 7218.3 & 12532.6 & 18152.7 \\
\hline 0.5 & 596.5 & 1333.4 & 2232.0 & 5594.2 & 8335.6 \\
\hline-0.5 & 429.0 & 960.3 & 1660.8 & 4482.4 & 6489.7 \\
\hline-1.5 & 504.1 & 1142.0 & 1875.0 & 5006.8 & 7264.9 \\
\hline-2.5 & 537.6 & 1176.7 & 2015.6 & 5276.8 & 7667.8 \\
\hline
\end{tabular}




\begin{tabular}{|c|c|c|c|c|c|}
\hline-3.5 & 593.0 & 1297.4 & 2239.0 & 5333.8 & 7483.6 \\
\hline-4.5 & 368.4 & 769.2 & 1367.4 & 2730.5 & 3635.7 \\
\hline-5.5 & 375.1 & 786.9 & 1458.8 & 3858.7 & 3376.8 \\
\hline-6.5 & 490.2 & 1041.4 & 1877.1 & 4100.6 & 5545.6 \\
\hline-7.5 & 468.7 & 1014.7 & 1839.3 & 4032.9 & 5383.1 \\
\hline-8.5 & 602.3 & 1340.3 & 2490.5 & 5325.6 & 6678.7 \\
\hline-9.5 & 269.0 & 592.2 & 1106.3 & 2203.8 & 2590.0 \\
\hline-10.5 & 264.9 & 547.3 & 877.9 & 1549.8 & 1625.5 \\
\hline-11.5 & 270.4 & 552.1 & 866.6 & 1471.6 & 1512.0 \\
\hline-12.5 & 756.2 & 1475.9 & 2691.6 & 4066.9 & 3927.4 \\
\hline-13.5 & 332.9 & 651.6 & 974.1 & 1483.7 & 1445.3 \\
\hline-14.5 & 419.3 & 838.0 & 1222.2 & 2023.2 & 1996.5 \\
\hline-15.5 & 481.5 & 952.7 & 1316.6 & 2128.4 & 2129.9 \\
\hline-16.5 & 498.6 & 993.5 & 1749.5 & 2857.7 & 3194.8 \\
\hline-17.5 & 466.6 & 904.8 & 1816.2 & 2819.6 & 3465.7 \\
\hline-18.5 & 440.5 & 855.5 & 1593.3 & 2614.0 & 3206.7 \\
\hline-19.5 & 486.1 & 998.1 & 1862.4 & 3322.4 & 3990.0 \\
\hline-20.5 & 545.2 & 1035.2 & 1963.5 & 3341.6 & 4197.2 \\
\hline-21.5 & 498.0 & 1127.2 & 2320.6 & 3568.9 & 4128.3 \\
\hline-22.5 & 1156.5 & 2403.8 & 4265.9 & 8155.3 & 9300.0 \\
\hline-23.5 & 1620.1 & 3237.6 & 5642.7 & 10412.1 & 12095.9 \\
\hline-24.5 & 1164.4 & 1991.9 & 3240.6 & 4921.0 & 6032.4 \\
\hline-25.5 & 1819.0 & 3098.8 & 4941.0 & 7549.2 & 9618.6 \\
\hline-26.5 & 4284.1 & 7028.3 & 10956.0 & 15811.2 & 20806.4 \\
\hline-27.5 & 3137.8 & 5123.4 & 8146.0 & 11697.3 & 15005.6 \\
\hline-28.5 & 1711.0 & 2836.8 & 4459.1 & 6559.2 & 8430.9 \\
\hline-29.5 & 2773.0 & 4562.9 & 7102.2 & 10370.2 & 13588.9 \\
\hline-30.5 & 1892.8 & 3143.0 & 4941.4 & 7231.5 & 9257.5 \\
\hline-31.5 & 3147.7 & 5123.9 & 8151.4 & 11472.4 & 14396.5 \\
\hline-32.5 & 2586.6 & 4202.7 & 6605.9 & 9138.3 & 11400.1 \\
\hline-33.5 & 6636.4 & 10702.0 & 17228.4 & 23607.0 & 30883.4 \\
\hline-34.5 & 5056.4 & 8243.1 & 13363.1 & 17825.3 & 19735.9 \\
\hline-35.5 & 809.1 & 1291.9 & 2103.8 & 2868.7 & 3576.0 \\
\hline-36.5 & 1302.4 & 1929.8 & 2842.7 & 3687.3 & 4686.1 \\
\hline-37.5 & 3626.2 & 5796.4 & 9346.7 & 13146.2 & 16936.8 \\
\hline-38.5 & 745.6 & 1170.5 & 1870.6 & 2494.7 & 3034.3 \\
\hline-39.5 & 288.8 & 435.3 & 661.9 & 837.9 & 970.1 \\
\hline-40.5 & 239.0 & 366.0 & 569.6 & 725.2 & 822.0 \\
\hline-41.5 & 584.6 & 849.6 & 1206.5 & 1559.3 & 1974.7 \\
\hline-42.5 & 526.9 & 817.9 & 1278.6 & 1731.6 & 2174.1 \\
\hline-43.5 & 500.0 & 710.4 & 969.3 & 1232.1 & 1550.4 \\
\hline-44.5 & 210.6 & 310.9 & 454.8 & 577.8 & 677.4 \\
\hline-45.5 & 300.1 & 424.9 & 582.5 & 722.8 & 911.7 \\
\hline-46.5 & 144.2 & 214.2 & 317.3 & 401.8 & 470.9 \\
\hline-47.5 & 67.6 & 110.1 & 183.0 & 242.3 & 247.5 \\
\hline-48.5 & 58.4 & 94.8 & 161.0 & 205.5 & 222.6 \\
\hline-49.5 & 54.1 & 88.2 & 146.6 & 194.1 & 198.3 \\
\hline-50.5 & 42.4 & 69.1 & 114.9 & 152.1 & 155.3 \\
\hline-51.5 & 119.8 & 124.9 & 126.4 & 159.6 & 181.4 \\
\hline-52.5 & 39.1 & 62.9 & 113.9 & 129.8 & 167.4 \\
\hline-53.5 & 35.4 & 57.1 & 101.0 & 120.1 & 145.4 \\
\hline-54.5 & 29.0 & 47.3 & 78.7 & 104.2 & 106.4 \\
\hline
\end{tabular}




\begin{tabular}{|c|c|c|c|c|c|}
\hline-55.5 & 0.0 & 0.0 & 0.0 & 0.0 & 0.0 \\
\hline-56.5 & 0.0 & 0.0 & 0.0 & 0.0 & 0.0 \\
\hline-57.5 & 0.0 & 0.0 & 0.0 & 0.0 & 0.0 \\
\hline-58.5 & 0.0 & 0.0 & 0.0 & 0.0 & 0.0 \\
\hline-59.5 & 0.0 & 0.0 & 0.0 & 0.0 & 0.2 \\
\hline-60.5 & 0.0 & 0.0 & 0.0 & 0.0 & 0.2 \\
\hline-61.5 & 0.0 & 0.0 & 0.0 & 0.0 & 0.2 \\
\hline-62.5 & 0.0 & 0.0 & 0.0 & 0.0 & 0.2 \\
\hline-63.5 & 0.0 & 0.0 & 0.0 & 0.0 & 0.2 \\
\hline-64.5 & 0.0 & 0.0 & 0.0 & 0.0 & 0.2 \\
\hline-65.5 & 0.0 & 0.0 & 0.0 & 0.0 & 0.2 \\
\hline-66.5 & 0.0 & 0.0 & 0.0 & 0.0 & 0.2 \\
\hline-67.5 & 0.0 & 0.0 & 0.0 & 0.0 & 0.2 \\
\hline-68.5 & 0.0 & 0.0 & 0.0 & 0.0 & 0.1 \\
\hline-69.5 & 0.0 & 0.0 & 0.0 & 0.0 & 0.1 \\
\hline-70.5 & 0.0 & 0.0 & 0.0 & 0.0 & 0.1 \\
\hline-71.5 & 0.0 & 0.0 & 0.0 & 0.0 & 0.1 \\
\hline-72.5 & 0.0 & 0.0 & 0.0 & 0.0 & 0.1 \\
\hline-73.5 & 0.0 & 0.0 & 0.0 & 0.0 & 0.1 \\
\hline-74.5 & 0.0 & 0.0 & 0.0 & 0.0 & 0.1 \\
\hline-75.5 & 0.0 & 0.0 & 0.0 & 0.0 & 0.1 \\
\hline-76.5 & 0.0 & 0.0 & 0.0 & 0.0 & 0.0 \\
\hline-77.5 & 0.0 & 0.0 & 0.0 & 0.0 & 0.0 \\
\hline-78.5 & 0.0 & 0.0 & 0.0 & 0.0 & 0.0 \\
\hline-79.5 & 0.0 & 0.0 & 0.0 & 0.0 & 0.0 \\
\hline-80.5 & 0.0 & 0.0 & 0.0 & 0.0 & 0.0 \\
\hline-81.5 & 0.0 & 0.0 & 0.0 & 0.0 & 0.0 \\
\hline-82.5 & 0.0 & 0.0 & 0.0 & 0.0 & 0.0 \\
\hline-83.5 & 0.0 & 0.0 & 0.0 & 0.0 & 0.0 \\
\hline-84.5 & 0.0 & 0.0 & 0.0 & 0.0 & 0.0 \\
\hline-85.5 & 0.0 & 0.0 & 0.0 & 0.0 & 0.0 \\
\hline-86.5 & 0.0 & 0.0 & 0.0 & 0.0 & 0.0 \\
\hline-87.5 & 0.0 & 0.0 & 0.0 & 0.0 & 0.0 \\
\hline-88.5 & 0.0 & 0.0 & 0.0 & 0.0 & 0.0 \\
\hline-89.5 & 0.0 & 0.0 & 0.0 & 0.0 & 0.0 \\
\hline
\end{tabular}




\section{A.2 READGRID.F}

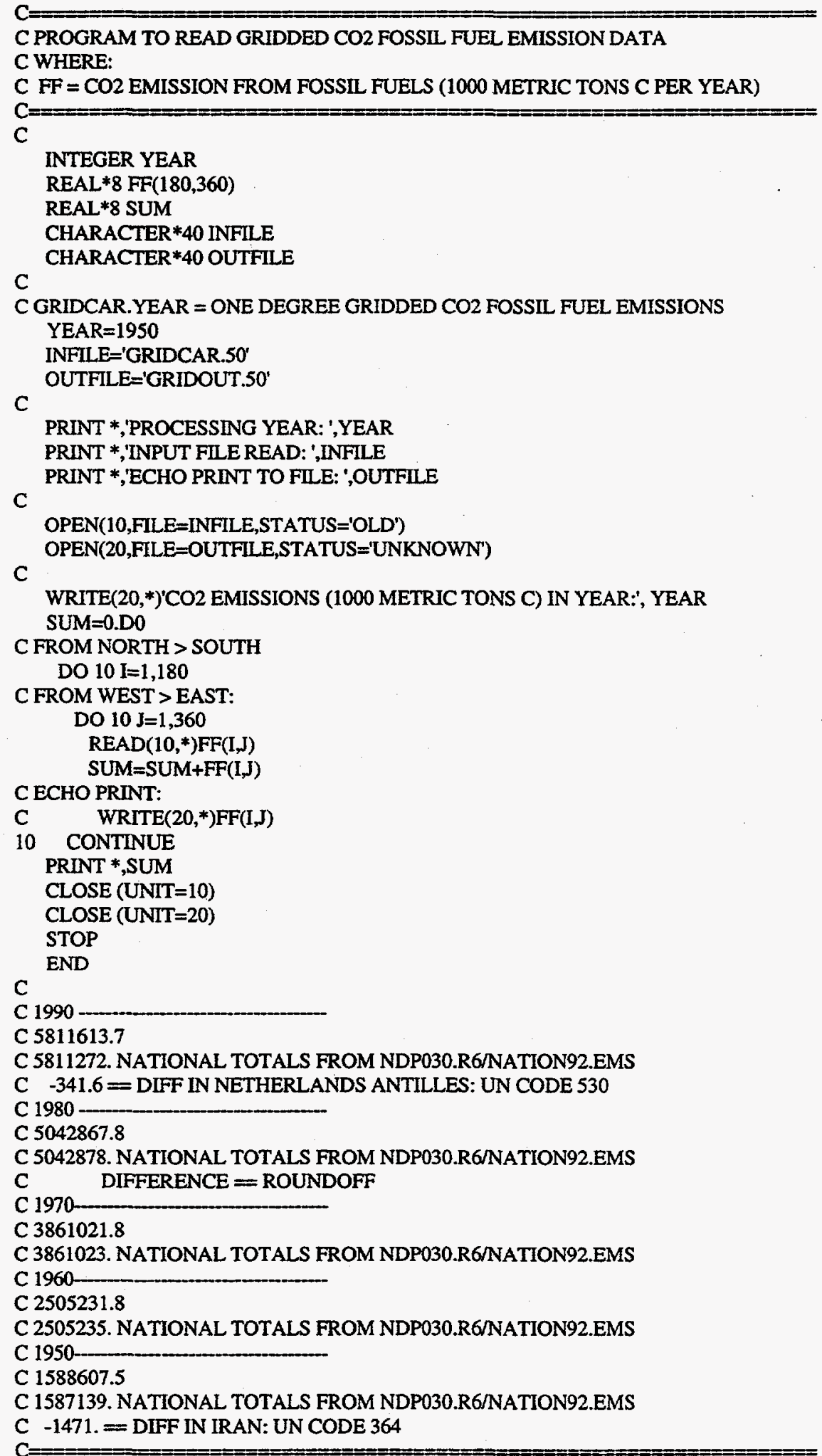




\section{A.3 READALL.F}

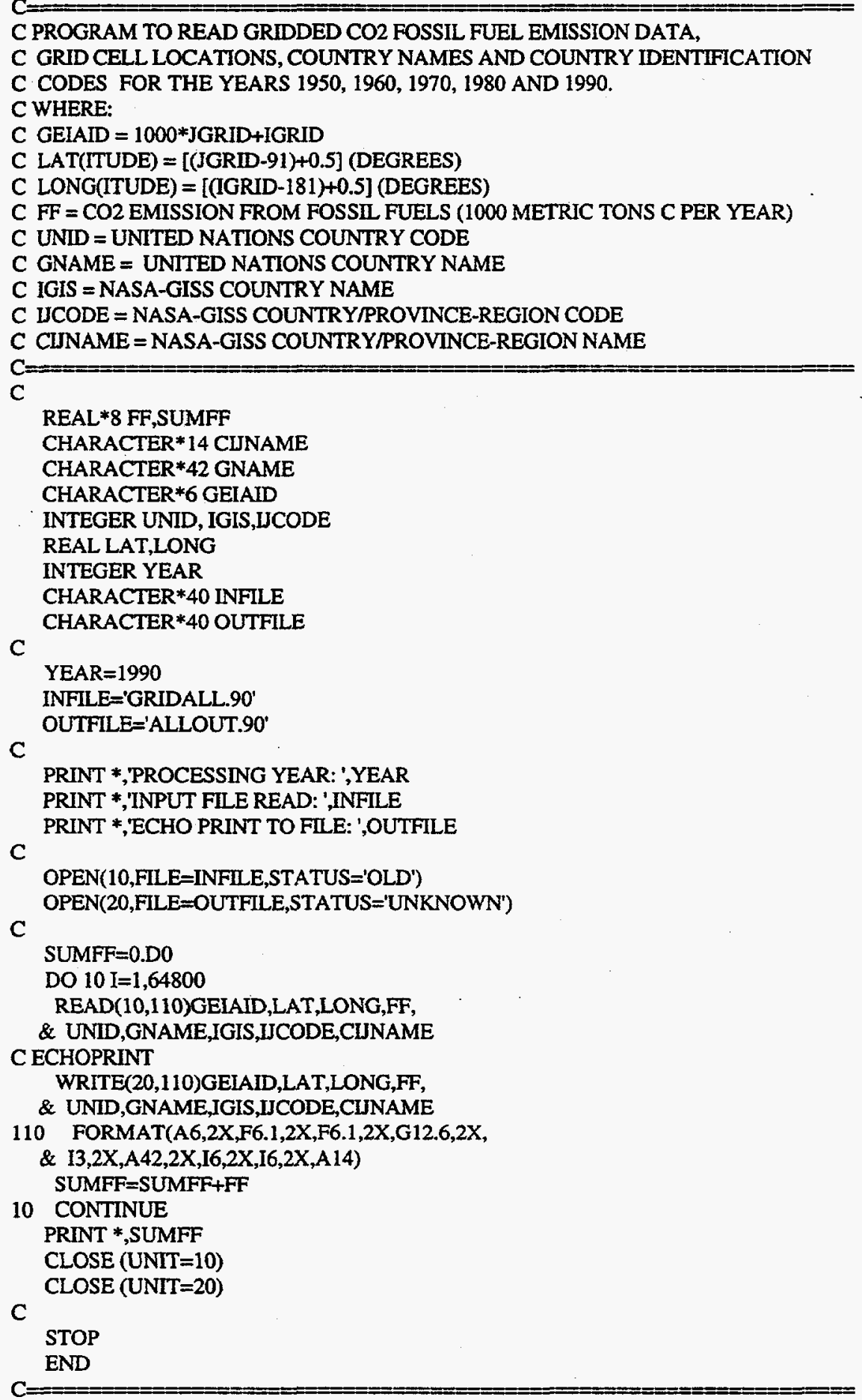




\section{A.4 ALL.SAS}

OPTIONS LS $=132$ PS $=32400$;

* SAS ${ }^{\mathrm{TM}}$ CODE TO PROCESS GRIDDED CO2 FOSSIL-FUEL EMISSION DATA,

* GRID CELL LOCATIONS, COUNTRY NAMES AND COUNTRY IDENTIFICATION

* CODES FOR THE YEARS 1950, 1960, 1970, 1980 AND 1990

* WHERE

* GEIAID $=1000 *$ JGRID+IGRID

* LAT(ITUDE) $=[($ JGRID-91)+0.5] (DEGREES)

* LONG(ITUDE) $=[($ IGRID-181)+0.5] (DEGREES)

* FF $=$ CO2 EMISSION FROM FOSSIL FUELS (1000 METRIC TONS C PER YEAR)

* UNID = UNITED NATIONS COUNTRY CODE

* GNAME = UNITED NATIONS COUNTRY NAME

* IGIS = NASA-GISS COUNTRY NAME

* IJCODE = NASA-GISS COUNTRY/PROVINCE-REGION CODE

* CIJNAME = NASA-GISS COUNTRYIPROVINCE-REGION NAME

* 1950;

DATA NEW5;

INFILE 'GRIDALL.50';

INPUT @1 GEIAID \$CHAR6. @9 LAT 6.1 @17 LONG 6.1 @25 FF5 12.6

$@ 39$ UNID 3. @44 GNAME \$CHAR42.

@88 IGIS 6. @95 IJCODE 6. @102 CIJNAME \$CHAR14.; RUN;

;

PROC SORT DATA=NEW5;

BY UNID;

PROC MEANS NOPRINT;

BY UNID;

ID GNAME IGIS;

VAR FF5;

OUTPUT OUT=FINAL SUM=SFF;

PROC PRINT;

VAR SFF GNAME IGIS UNID;

RUN;

* 1960;

DATA NEW6;

INFILE 'GRIDALL.60';

INPUT @1 GEIAID \$CHAR6. @9 LAT 6.1 @17 LONG 6.1 @25 FF6 12.6

@39 UNID 3. @44 GNAME \$CHAR42.

@88 IGIS 6. @95 UJCODE 6. @102 CIJNAME \$CHAR 14.;

RUN;

PROC SORT DATA=NEW6;

BY UNID;

PROC MEANS NOPRINT;

BY UNID;

ID GNAME IGIS;

VAR FF6;

OUTPUT OUT=FINAL SUM=SFF;

PROC PRINT;

VAR SFF GNAME IGIS UNID;

RUN;

; 
* 1970;

DATA NEW7;

INFILE 'GRIDALL.70';

INPUT @1 GEIAID \$CHAR6. @9 LAT 6.1 @17 LONG 6.1 @25 FF7 12.6 @39 UNID 3. @44 GNAME \$CHAR42.

@88 IGIS 6. @95 UCODE 6. @102 CIJNAME \$CHAR14;

RUN;

PROC SORT DATA=NEW7;

BY UNID;

PROC MEANS NOPRINT;

BY UNID;

ID GNAME IGIS;

VAR FF?;

OUTPUT OUT $=$ FINAL SUM=SFF;

PROC PRINT;

VAR SFF GNAME IGIS UNID;

RUN;

;

* 1980;

DATA NEW8;

INFILE 'GRIDALL.80';

INPUT @1 GEIAID \$CHAR6. @9 LAT 6.1 @17 LONG 6.1 @25 FF8 12.6 @39 UNID 3. @44 GNAME \$CHAR42.

@88 IGIS 6. @95 IJCODE 6. @102 CUJNAME \$CHAR14.;

RUN;

PROC SORT DATA=NEW8;

BY UNID;

PROC MEANS NOPRINT;

BY UNID;

ID GNAME IGIS;

VAR FF8;

OUTPUT OUT=FINAL SUM=SFF;

PROC PRINT;

VAR SFF GNAME IGIS UNID;

RUN;

;

* 1990;

DATA NEW9;

INFILE 'GRIDALL.90';

INPUT @1 GEIAID \$CHAR6. @9 LAT 6.1 @17 LONG 6.1 @25 FF9 12.6 @39 UNID 3. @44 GNAME SCHAR42.

@88 IGIS 6. @95 IJCODE 6. @102 CIJNAME \$CHAR14.; RUN;

PROC SORT DATA=NEW9;

BY UNID;

PROC MEANS NOPRINT;

BY UNID;

ID GNAME IGIS;

VAR FF9;

OUTPUT OUT=FINAL SUM=SFF;

PROC PRINT;

VAR SFF GNAME IGIS UNID;

RUN;

; 


\section{A.5 READMOD.F}

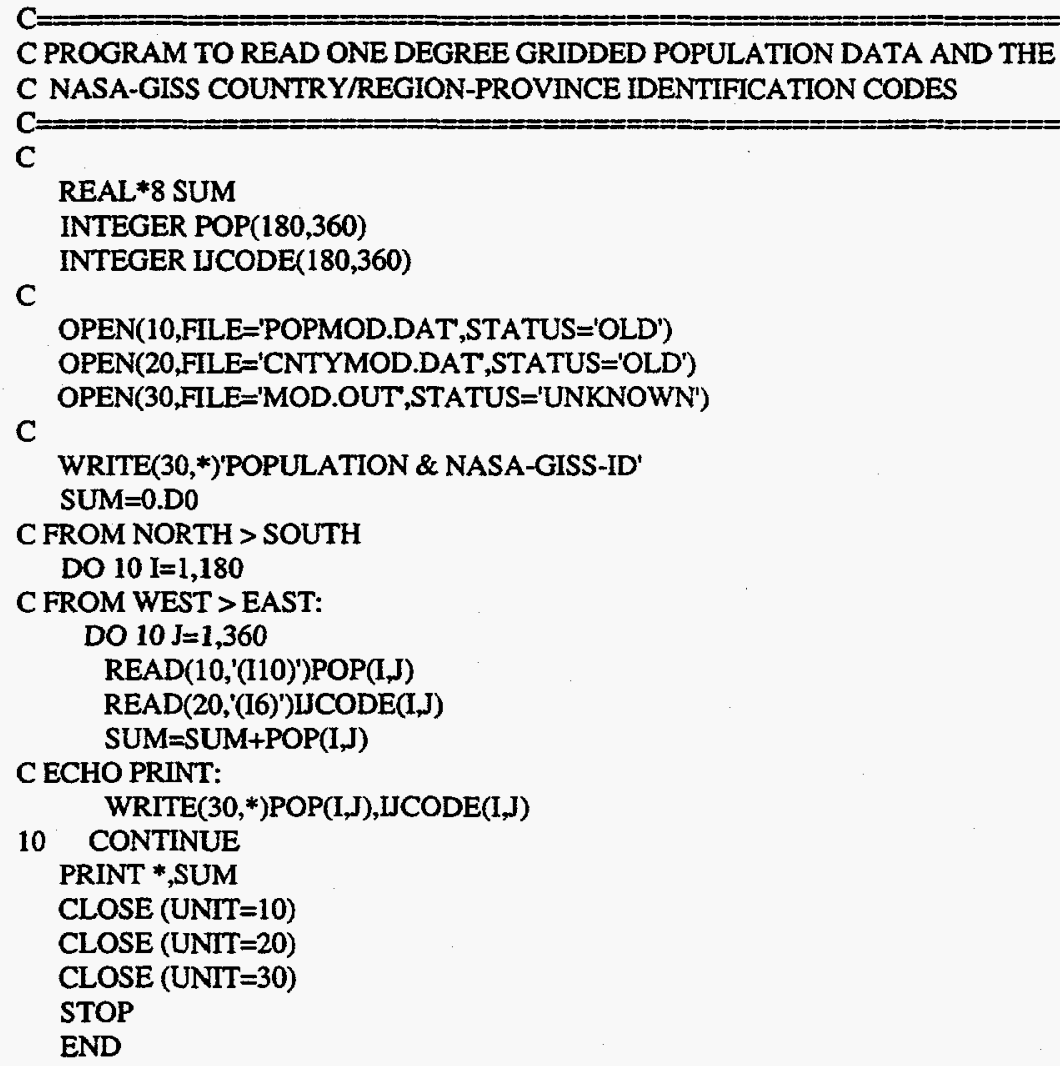




\section{A.6 READCODE.F}

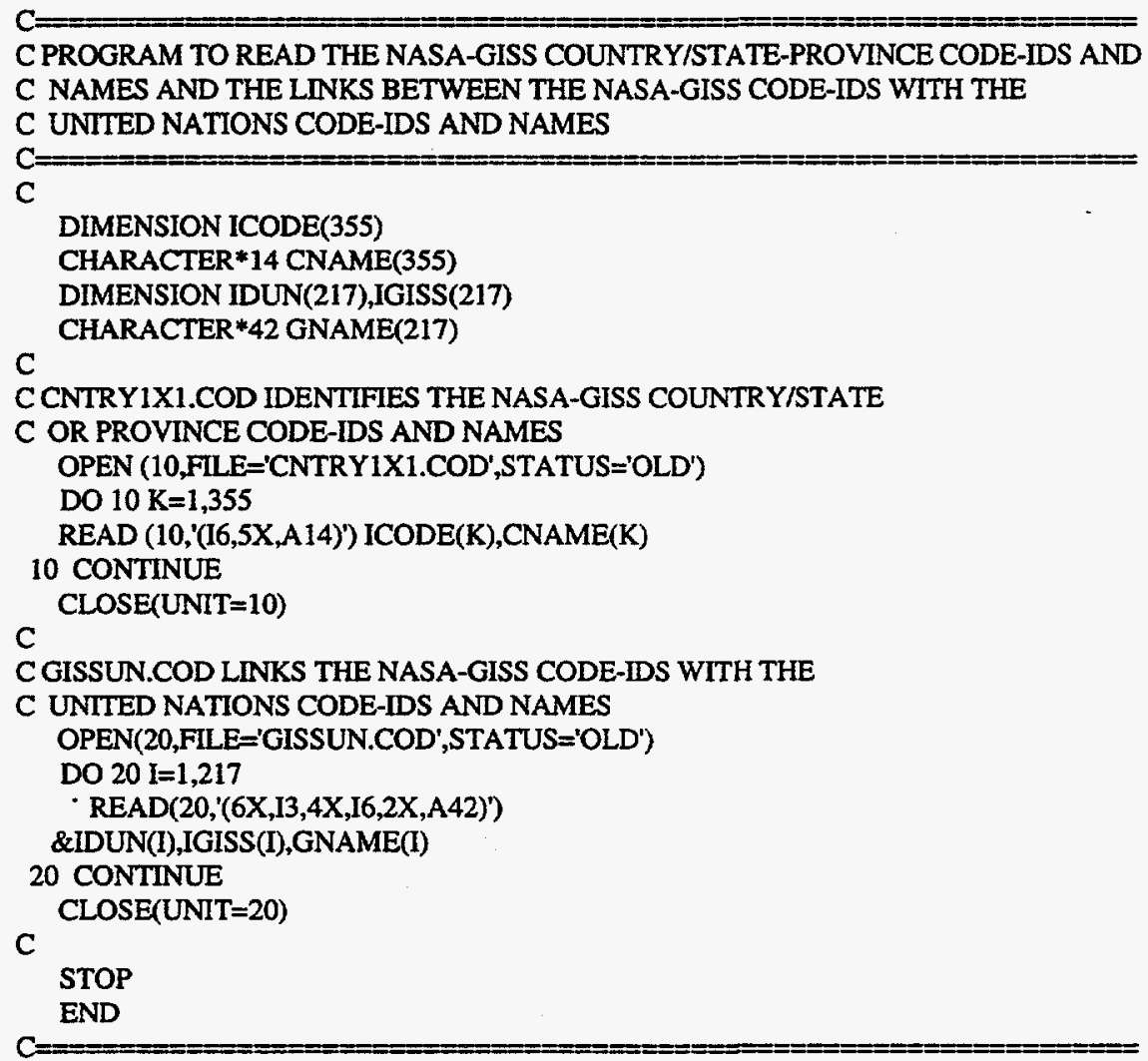




\section{A.7 INTEGRAT.F}

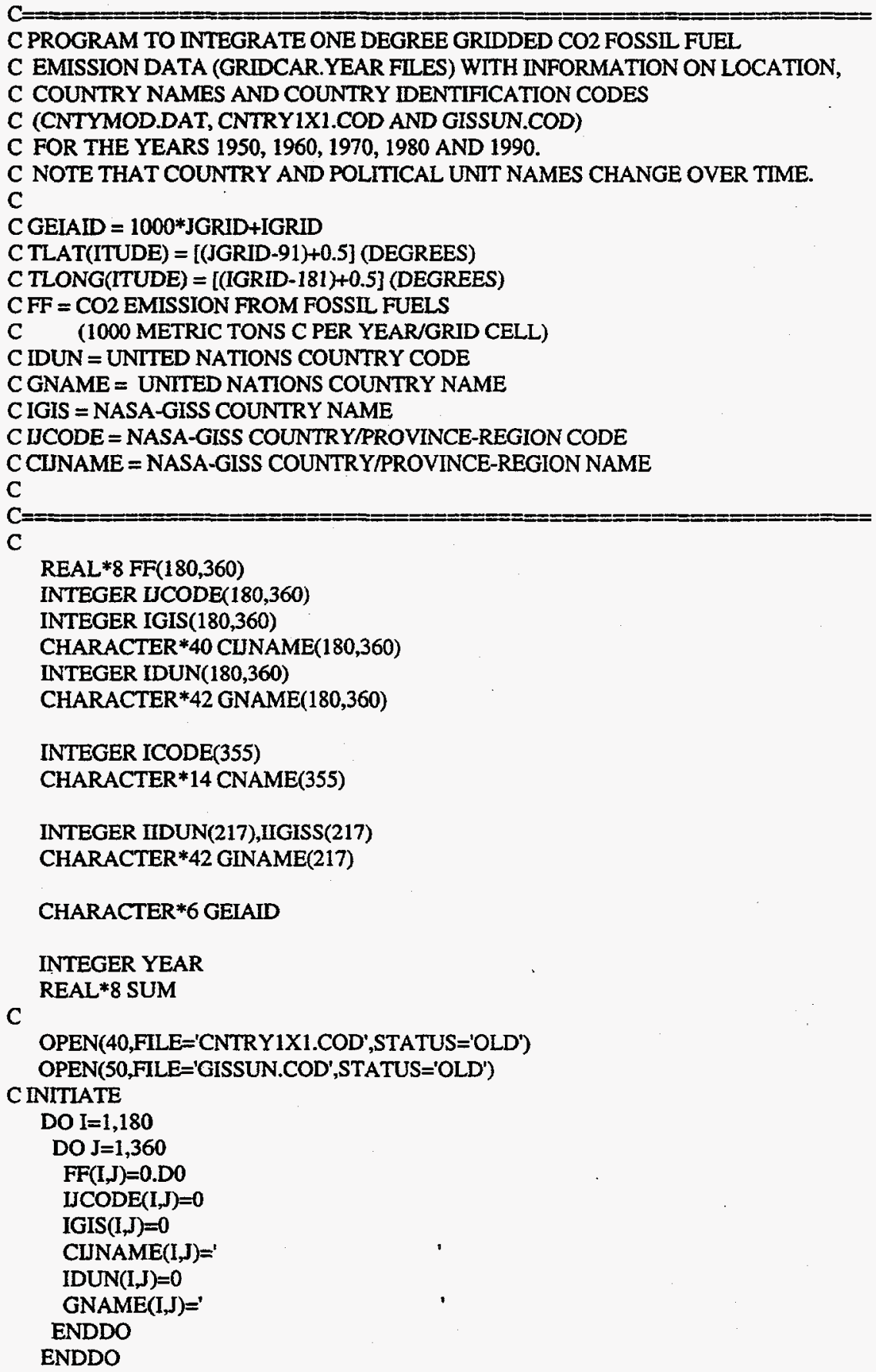


DO $\mathrm{IJ}=1,5$

SUM $=0 . D 0$

IF(IJ.EQ.1) YEAR $=1950$

IF(U.EQ.2) YEAR $=1960$

IF(UJ.EQ.3) YEAR $=1970$

IF(IJ.EQ.4) YEAR $=1980$

IF(UJ.EQ.5) YEAR $=1990$

IF(IJ.EQ.1) OPEN(10,FILE='GRIDCAR.50',STATUS='OLD')

IF(IJ.EQ.2) OPEN(10,FILE='GRIDCAR.60',STATUS='OLD')

IF(IJ.EQ.3) OPEN(10,FILE='GRIDCAR.70',STATUS='OLD')

IF(U.EQ.4) OPEN(10,FILE='GRIDCAR.80',STATUS='OLD')

IF(IJ.EQ.5) OPEN(10,FILE='GRIDCAR.90',STATUS='OLD')

IF(IJ.EQ.1) OPEN(30,FILE='GRIDALL.50',STATUS='UNKNOWN')

IF(IJ.EQ.2) OPEN(30,FILE='GRIDALL.60',STATUS='UNKNOWN')

IF(IJ.EQ.3) OPEN(30,FILE='GRIDALL.70',STATUS='UNKNOWN')

IF(IJ.EQ.4) OPEN(30,FILE='GRIDALL.80',STATUS='UNKNOWN')

C IF(IJ.EQ.5) OPEN(30,FILE='GRIDALL.90',STATUS='UNKNOWN')

C

OPEN(20,FILE='CNTYMOD.DAT,STATUS='OLD')

TLONG $=-179.5$

TLAT $=90.5$

C FROM NORTH $>$ SOUTH

DO $10 \mathrm{I}=1,180$

TLAT $=$ TLAT-1.D0

TLONG $=-179.5$

C FROM WEST > EAST:

DO $10 \mathrm{~J}=1,360$

C WRITE OUT EACH GRIDCELL:

JGRID $=$ TLAT+91.D0-0.5D0

C

IGRID=TLONG+181.D0-0.5D0

GEIAID $=' 000000^{\prime}$

IF (JGRID.LE.9) THEN

WRITE (GEIAID(3:3),'(I1)') JGRID

ELSEIF (JGRID.LE.99) THEN

WRITE (GEIAID(2:3),'(12)') JGRID

ELSEIF (JGRID.LE.999) THEN

WRITE (GEIAID(1:3),'(13)') JGRID

ENDIF

IF (IGRID.LE.9) THEN

WRITE (GEIAID(6:6),'(I1)') IGRID

ELSEIF (IGRID.LE.99) THEN

WRITE (GEIAID(5:6),'(12)') IGŔID

ELSEIF (IGRID.LE.999) THEN

WRITE (GEIAID(4:6),'(13)') IGRID

ENDIF

C

$\operatorname{READ}(10, *) \mathrm{FF}(1, \mathrm{~J})$

C

$\operatorname{READ}\left(20,{ }^{\prime}(\mathrm{I} 6)^{\prime}\right) \mathrm{LJCODE}(\mathrm{I}, \mathrm{J})$

C PROCESS CHANGES OVER TIME:

C

C CZECHOSLOVAKIA

IF (IJCODE(I,J).EQ.4102) UJCODE(I,J) $=4100$

IF (IJCODE(I,J).EQ.4101) UJCODE(I,J) $=4100$ 


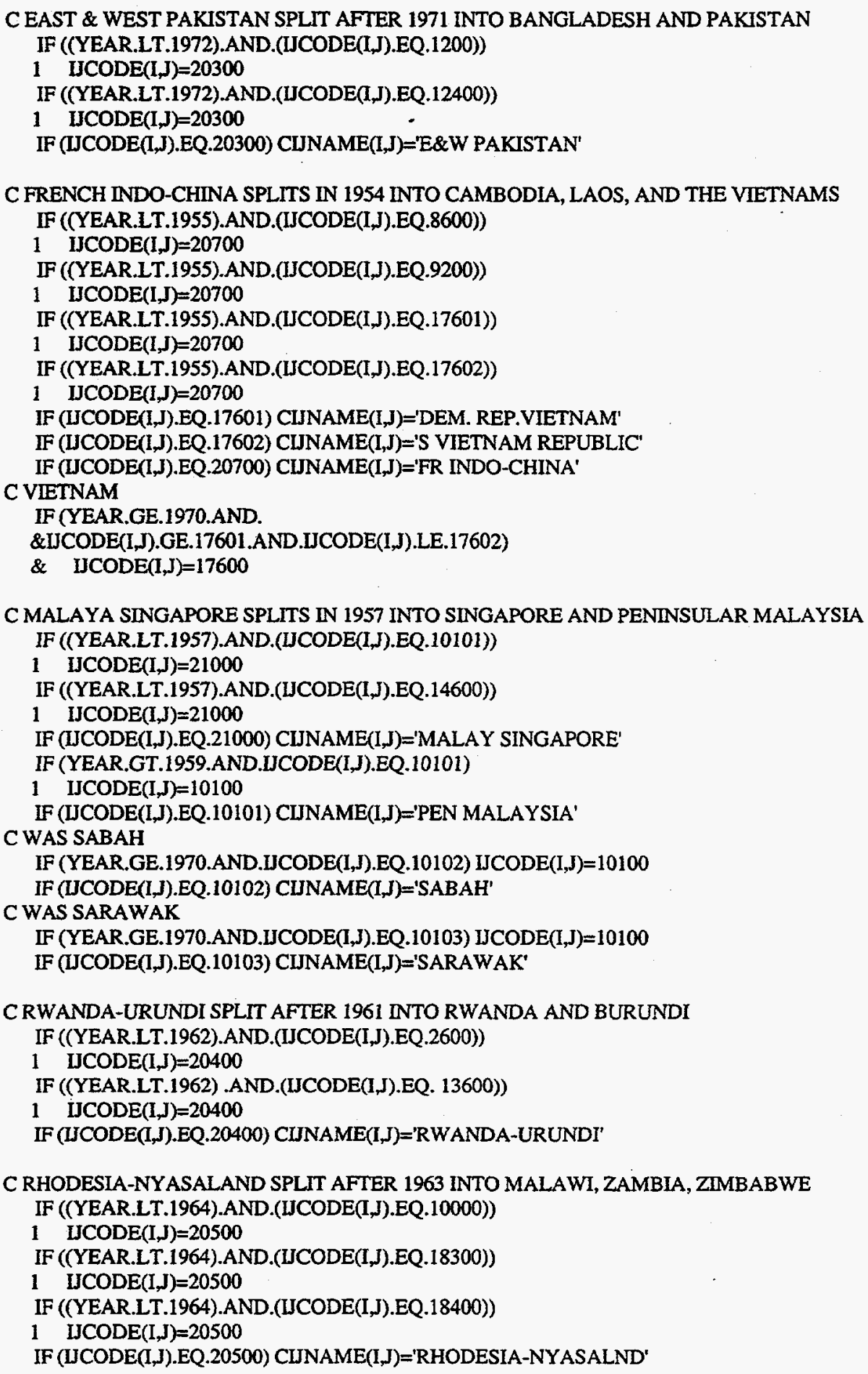

C MALAYA SINGAPORE SPLITS IN 1957 INTO SINGAPORE AND PENINSULAR MALAYSIA IF ((YEAR.LT.1957).AND.(IJCODE(IJ).EQ.10101)) 


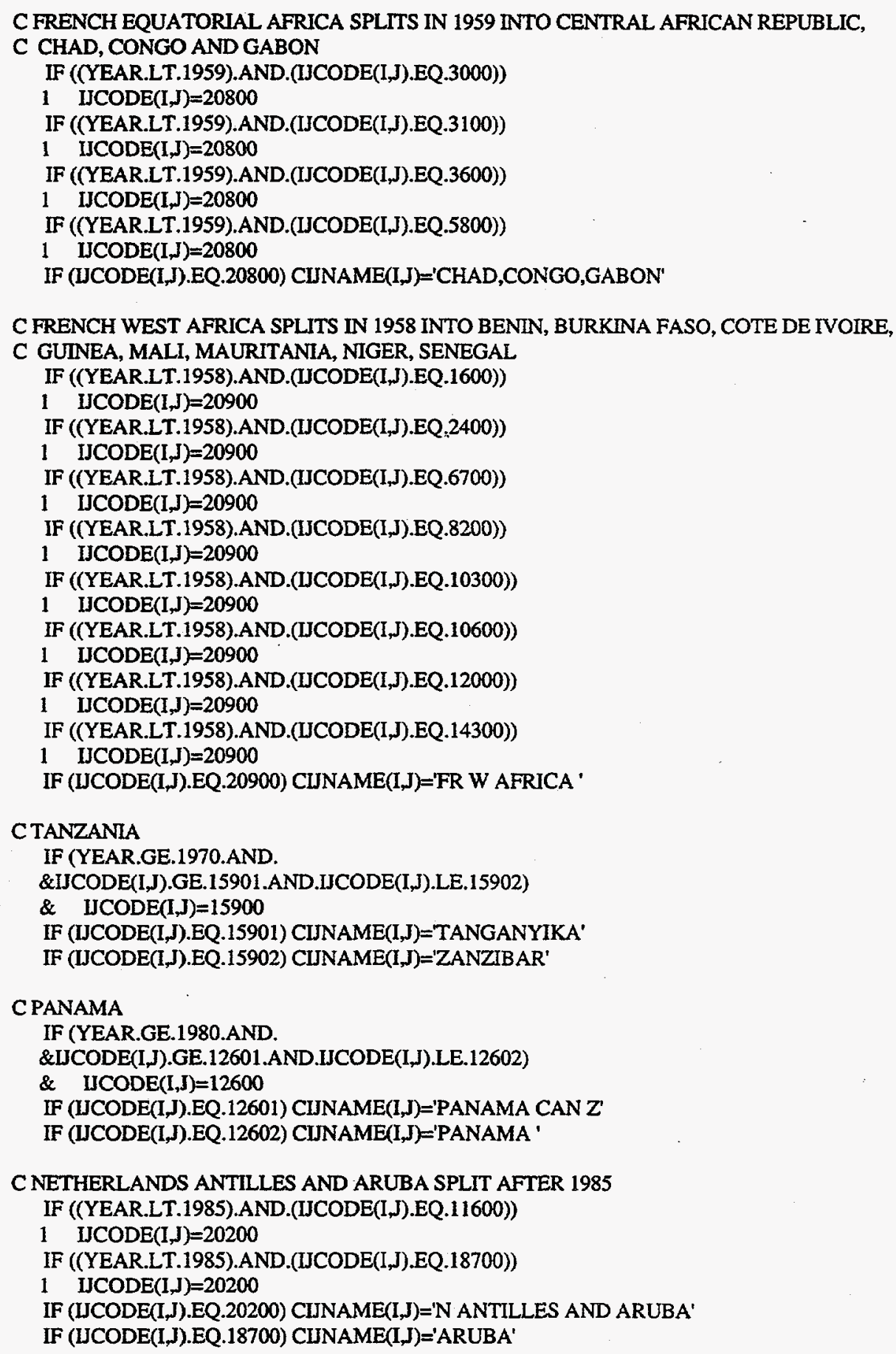

C NETHERLANDS ANTILLES AND ARUBA SPLIT AFTER 1985 IF ((YEAR.LT.1985).AND.(IJCODE(I,J).EQ.11600)) 




C CHRISTMAS ISLAND HAS DATA FOR 1970-1983, OTHERWISE INCLUDED IN AUSTRALIA IF ((YEAR.GT.1969).AND.(YEAR.LT.1984)) THEN 


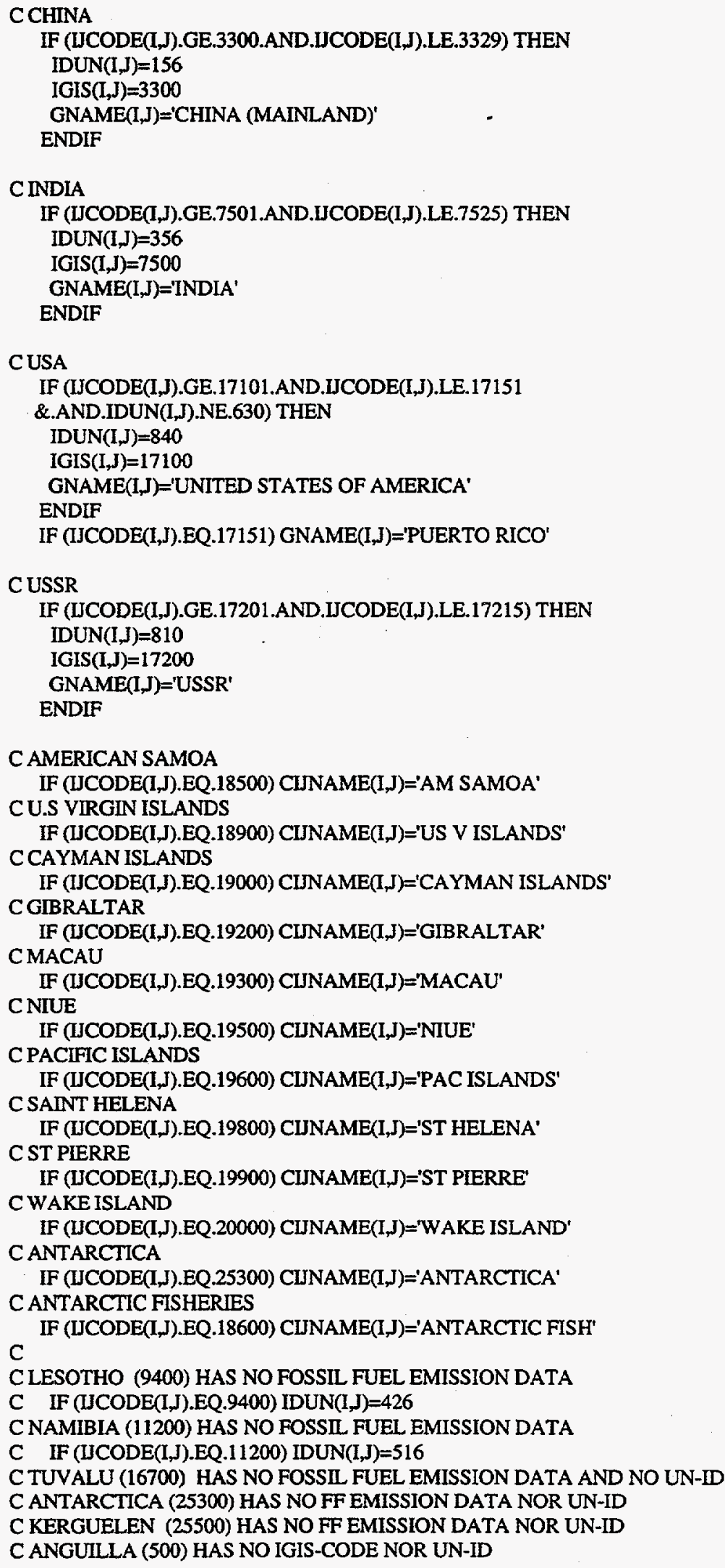


C

DO $K=1,355$

IF(I.EQ.1.AND.J.EQ.1.AND.IJ.EQ.1)

\& $\operatorname{READ}\left(40,{ }^{\prime}(16,5 X, A 14)^{\prime}\right)$ ICODE(K),CNAME(K)

ENDDO

DO $K=1,355$

IF (ICODE(K).EQ.JJCODE(I,J)) THEN

CIJNAME $(1, J)=$ CNAME $(K)$

GOTO 911

ENDIF

ENDDO

911 CONTINUE

DO $K=1,217$

IF(I.EQ.1.AND.J.EQ.1.AND.IJ.EQ.1)

\& $\operatorname{READ}\left(50,(6 \mathrm{X}, 13,4 \mathrm{X}, 16,2 \mathrm{X}, \mathrm{A} 42)^{\prime}\right)$

\& IIDUN(K),IIGISS(K),GINAME(K)

ENDDO

DO $\mathrm{K}=1,217$

IF (IIGISS(K).EQ.JJCODE(I,J)) THEN

GNAME $(\mathbf{I}, J)=$ GINAME $(K)$

IDUN(I,J) $=\operatorname{IIDUN}(\mathrm{K})$

IGIS $(I, J)=\operatorname{IIGISS}(\mathrm{K})$

GOTO 912

ENDIF

ENDDO

912 CONTINUE

IF(I.EQ.1.AND.J.EQ.1.AND.IJ.EQ.1) CLOSE(UNIT=40)

IF(I.EQ.1.AND.J.EQ.1.AND.IJ.EQ.1) CLOSE(UNIT=50)

WRITE(30,'(A6,2X,2(F6.1,2X),G12.6,2X,

$\& \mathrm{I} 3,2 \mathrm{X}, \mathrm{A} 42,2 \mathrm{X}$,

$\left.\& \mathrm{I} 6,2 \mathrm{X}, \mathrm{I6}, 2 \mathrm{X}, \mathrm{A} 14)^{\prime}\right)$

\&GEIAID,TLAT,TLONG,FF(I,J),

\&IDUN(I,J),GNAME(I,J),

\&IGIS(I,J),JJCODE(I,J),CLNAME(I,J)

C

$S U M=S U M+F F(I, J)$

TLONG=TLONG+1.D0

10 CONTINUE

C

PRINT *,'IN YEAR:',YEAR,' CO2 EMISSIONS=',SUM,

\&' IN 1000 METRIC TONS C

C IN YEAR: $\quad 1950$ CO2 EMISSIONS $=1588607.5$ IN 1000 METRIC TONS C C IN YEAR: $\quad 1960$ CO2 EMISSIONS $=2505231.8$ IN 1000 METRIC TONS C

C IN YEAR: $\quad 1970$ CO2 EMISSIONS $=3861021.8$ IN 1000 METRIC TONS C CIN YEAR: $\quad 1980$ CO2 EMISSIONS $=5042867.8$ IN 1000 METRIC TONS C C IN YEAR: $\quad 1990$ CO2 EMISSIONS $=5811613.7$ IN 1000 METRIC TONS C

C

CLOSE (UNIT $=10$ )

CLOSE (UNIT $=20$ )

CLOSE (UNIT $=30$ )

REWIND 10

REWIND 20

REWIND 30 


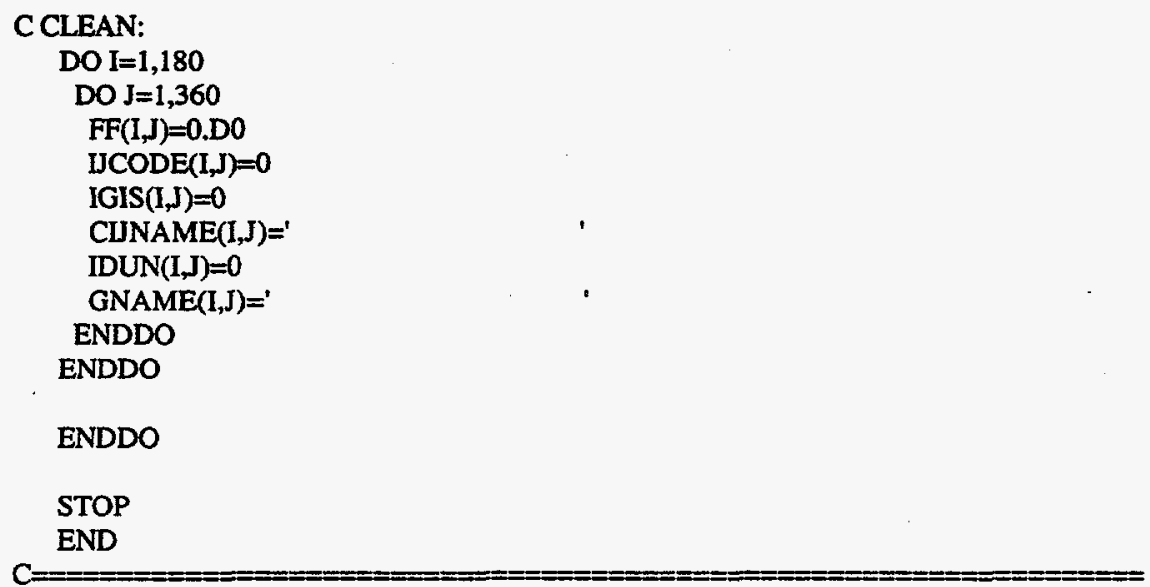




\section{INTERNAL DISTRIBUTION}

1. T. A. Boden

2. A. L. Brenkert

3. M. D. Burtis

4. R. M. Cushman

5. S. G. Hildebrand

6. S. V. Jennings

7. S. B. Jones

8. D. P. Kaiser

9. P. Kanciruk

10. A. W. King

11. A. Kozyr
12. G. Marland

13. W. M. Post III

14 D. E. Shepherd

15. D. S. Shriner

16. L. D. Voorhees

17. Central Research Library

18-32. ESD Library

33-34. Laboratory Records Department

35. Laboratory Records Department ORNL- RC

36. ORNL Patent Section

37. Y-12 Technical Library

\section{EXTERNAL DISTRIBUTION}

38. Robert J. Andres, University of Alaska, Institute of Northern Engineering, School of Engineering, Fairbanks, AK 99775

39. Shelton S. Alexander, Pennsylvania State University, Department of Geosciences, 537 Deike Building, State College, PA 16802

40. William E. Asher, University of Washington, Joint Inst. for the Study of the Atmos. \& the Ocean, Box 354235, Seattle, WA 98195

41. Jeff Banasek, UIC, Inc., P.O. Box 83, 1225 Channahon Road, Joliet, II 60434

42. Robert Bidigare, University of Hawaii, Department of Oceanography, 1000 Pope Road, Honolulu, HI 96822

43. Harry L. Boston, Director, Environmental Restoration Program, Oak Ridge National Laboratory, P.O. Box 2008, Oak Ridge, Tennessee 37831-6402

44. Peter G. Brewer, Monterey Bay Aquarium Res. Inst., P.O. Box 628, 7700 Sandholt Rd., Moss Landing, CA 95039

45. Michelle Broido, US Department of Energy, Environmental Sciences Div., ER-74, 19901 Germantown Road, Germantown, MD 20874

46. O. B. Brown, University of Miami, 4500 Rickenbacker Causeway, Miami, FL 33149 
47. L. Brugmann, Stockhom University, Dept. of Geology and Geochemistry, S-106 91 Stockholm, Sweden

48. Robert H. Byrne, University of South Florida, Department of Marine Science, 140 Seventh Avenue, S, Saint Petersburg, FL 33701

49. Patrick A. Crowley, US Department of Energy, Environmental Sciences Div., ER-74, 19901 Germantown Rd., Germantown, MD 20874

50. E. G. Cumesty, ORNL Site Manager, Department of Energy, Oak Ridge National Laboratory, P.O. Box 2008, Oak Ridge, TN 37831-6269

51. G. Cutter, Old Dominion University, Dept. of Oceanography, Norfolk, VA 23529

52. Roger C. Dahlman, US Department of Energy, Environmental Sciences Div., ER-74, 19901 Germantown Rd., Germantown, MD 20874

53. Giovanni Daneri, CEA Universidad del Mar, Dept. de Oceanografia y, Biologia Pesquera, Amunaategui 1838, Vina Del Mar, Chile

54. Database Section, Natl. Inst. for Envir. Studies, Center for Global Envir. Research, 16-2 Onogawa, Tsukuba, Ibaraki 305, Japan

55. Fred A. Donath, Institute for Environmental Education, Geological Society of America, 1006 Las Posas, San Clemente, California 92673

56. Jerry W. Elwood, US Department of Energy, Office of Energy Research, ER-74, 19901 Germantown Rd., Germantown, MD 20874

57. William R. Emanuel, Environmental Sciences Department, University of Virginia, Clark Hall, Charlottesville, VA 22903

58. Gerd Esser, Justus-Liebig-University, Inst. for Plant Ecology, Heinrich-Buff-Ring 38, D-35392 Giessen, Germany

59. Wanda Ferrell, US Department of Energy, Environmental Sciences Division, ER-74, 19901 Germantown Rd., Germantown, MD 20874

60. Diana W. Freckman, College of Natural Resources, 101 Natural Resources Building, Colorado State University, Fort Collins, Colorado 80523

61. Inez Y. S. Fung, University of Victoria, School of Earth \& Ocean Sciences, P.O. Box 1700, MS 4015, Victoria, B.C. V8W 2Y2, Canada 
62. Richard H. Gammon, University of Washington, Chemistry Department, Box 351700, Seattle, WA 98195

63. Jean-Pierre Gattuso, Observatoire Oceanologique Europeen, Avenue Saint-Martin, MC-98000, Monaco

64. Catherine M. Goyet, Woods Hole Oceanographic Inst., Marine Chemistry \& Geochemistry Dept., 360 Woods Hole Road, MS \#25, Woods Hole, MA 02543

65. David O. Hall, University of London, Div. of Biosphere Sciences, Kings's College Longon, Campden Hill Road, London W8 7AH, United Kingdom

66. A. Hittelman, WDC-A for Solid Earth Geophysics, NOAA Code E/GC1, 325 Broadway, Boulder, CO 80303

67. H. Hodgson, British Library, Boston Spa, DSC, Special Acquisitions, Wetherby, West Yorkshire, LS23 7BQ, United Kingdom

68. Huasheng Hong, Xiamen University, Environmental Science Res. Centre, Post Code 361005, Mail Box 1085, Xiamen, Fujian, People's Rep China

69. Carroll A. Hood, GCRIO, 2250 Pierce Road, Bay City, MI 48710

70. John C. Houghton, US Department of Energy, Environmental Sciences Div., ER-74, 19901 Germantown Rd., Germantown, MD 20874

71. David M. Karl, University of Hawaii, Dept. of Oceanography, 1000 Pope Road, Honolulu, HI 96822

72. Thomas R. Karl, National Climatic Data Center, 151 Patton Ave., Federal Bldg., Rm. 516E, Asheville, NC 28801

73. Charles D. Keeling, Scripps Inst. of Oceanography, University of California-San Diego, Mail Code 0220, 9500 Gilman Drive, 2314 Ritter Hall, La Jolla, CA 92093

74. Stephan Kempe, Schnittspahnstr. 9, D-64287 Darmstadt, Germany

75. K.-R. Kim, Seoul National University, Dept. of Oceanology, Seoul 151-7442, Korea

76. John C. Klink, Miami University, Department of Geography, 217 Shideler Hall, Oxford, OH 45056 
77. E. Lewis, Brookhaven National Laboratory, Oceanographic Sci. Div., Upton, NY 11973

78. Jonathan J. Lloyd, Australian National University, Res. School of Biological Sciences, GPO Box 475, Canberra, ACT 2601, Australia

79. Jennifer A. Logan, Harvard University, Center for Earth \& Planetary, Physics 108 Pierce Hall, 29 Oxford Street, Cambridge, MA 02138

80. Peter Lunn, US Department of Energy, Environmental Sciences Div., ER-74, 19901 Germantown Rd., Germantown, MD 20874

81. Thomas H. Mace, USEPANatl. Data Processing Div., MD-34, 79 TW Alexander Drive, Bldg. 4201, Durham, NC 27711

82. Elaine Matthews, NASA, Goddard Institute for Space Studies, 2880 Broadway, New York, NY 10025

83. James J. McCarthy, Harvard University, Museum of Comparative Zoology, 26 Oxford Street, Cambridge, MA 02138

84. P. Middleton, Science \& Policy Assoc., Inc., 3445 Penrose Place, Suite 140, Boulder, CO 80301

85. Frank J. Millero, University of Miami, RSMAS, 4600 Rickenbacker Causeway, Miami, FL 33149

86. R. E. Munn, University of Toronto, Inst. for Environmental Studies, Haultain Bldg. 170 College St., Toronto, Ontario M5S 1A4, Canada

87. Shohei Murayama, Natl. Inst. for Resources \& Envir., Environmental Assessment Dept., 16-3 Onogawa, Tsukuba, Ibaraki 305, Japan

88. Shuzo Nishioka, Natl. Inst. for Envir. Studies, Global Environment Research Division, 16-2 Onogawa, Tsukuba, Ibaraki 305, Japan

89-90. Office of Scientific and Technical Information, P. O. Box 62, Oak Ridge, Tennessee 37831

91. Office of Assistant Manager for Energy Research and Development, U.S. Department of Energy, Oak Ridge Operations, P. O. Box 2001, Oak Ridge, Tennessee 37831-8600 
92. Jao Ryoung Oh, Korea Ocean Research, \& Development Inst., Chemical Oceanography Div., An San P.O. Box 29, Seoul 4325-600, Korea

93. Jos G.J. Olivier, RIVM, Lab for Waste Materials \& Emissions, P.O. Box 1, NL-3720 BA Bilthoven, Netherlands

94. Bobbi Parra, US Department of Energy, Environmental Sciences Division, ER-74, 19901 Germantown Rd., Germantown, MD 20874

95. William Parton, Colorado State University, Natural Resource Ecology Lab, Fort Collins, CO 80523

96. Ari Patrinos, US Department of Energy, ER-74, 19901 Germantown Rd., Germantown, MD 20874

97. Tsung-Hung Peng, NOAA/AOML, Ocean Chemistry Division, 4301 Rickenbacker Causeway, Miami, FL 33149

98. B. Preselin, University of California, Dept. of Biological Sciences, Santa Barbara, CA 93106

99. Paul D. Quay, University of Washington, School of Oceanography, Box 357940, Seattle, WA 98195

100. Roberta Y. Rand, USDA, Global Change Data \& Info. Management, 10301 Baltimore Blvd., Beltsville, MD 20705

101. S. Ichtiaque Rasool, 52 Blvd. de Sebastopol, 5th Floor, 75003 Paris, France

102. Joachim Ribbe, University of Washington, Joint Institute for the Study of the Atmosphere and Oceans, Box \# 35425, Seattle, WA 98195

103. Michael R. Riches, US Department of Energy, OHER, ER-74, 19901 Germantown Rd., Germantown, MD 20874

104. Jorge L. Sarmiento, Princeton University, Atmospheric and Oceanic, Sciences Program, P.O. Box CN710, Sayre Hall, Princeton, NJ 08544

105. G. S. Sayler, Director, Center for Environmental Biotechnology, The University of Tennessee, 1015 Research Drive, Suite 100, Knoxville, Tennessee 379322567

106. Alan M. Shiller, Univ. of Southern Mississippi, Center for Marine Science, Stennis Space Center, Bay Saint Louis, MS 39529 
107. Kiminori Shitashima, Central Research Institute of Electric Power Industry, Marine Science Group, 1646, Abiko, Abiko-city, Chiba, 270-11, Japan

108-207. Timmothy W. Stamm, CDIAC, University of Tennessee, EERC, 10521 Research Drive, Suite 100, Knoxville, TN 37932

208. Michel H. C. Stoll, Netherlands Inst. for Sea Research, Dept. MCG, P. O. Box 59, 1790 Abden Burg-Texel, Netherlands

209. Eric T. Sundquist, US Geological Survey, Quissett Campus, Branch of Atlantic Marine Geology, Woods Hole, MA 02543

210. Taro Takahashi, Columbia University, Lamont-Doherty Earth Obs., Climate/Environment/Ocean Div., Rt. 9W, Palisades, NY 10964

211. Pieter P. Tans, Natl. Oceanic \& Atm. Adm., CMDL, Maincode R/E/CG1, 325 Broadway, Boulder, CO 80303

212. John A. Taylor, Australian Natl. University, CRES, GPO Box 4, Canberra, ACT 0200, Australia

213. John R. G. Townshend, University of Maryland, Dept. of Geography, 1113 Lefrak Hall, College Park, MD 20742

214. J. Tucker, Marine Biological Lab, Woods Hole, MA 02543

215. Douglas W. R. Wallace, Brookhaven National Lab, Oceanographic \& Atmos. Sciences Div., P.O. Box 5000, Upton, NY 11973

216. Carol Watts, Natl. Oceanic \& Atm. Adm., Central Library, 1315 East-West Hwy., 2nd Floor, SSMC 3, Silver Spring, MD 20910

217. Ray F. Weiss, Scripps Inst. of Oceanography, University of California, Mail Code A-020, Room 2271, Ritter Hall, La Jolla, CA 92093

218. Chi Shing Wong, Government of Canada, Institute of Ocean Sciences, P.O. Box 6000,9860 West Saanich Road, Sidney, BC V8L 4B2, Canada

219. L. Xu, Xiamen University, Environmental Science, Research Center, Xiamen, Fujian, People's Rep China

220. Yoshifumi Yosuoka, Natl. Inst. for Envir. Studies, Center Global Environment Research, 16-2 Onogawa, Tsukuba, Ibaraki 305, Japan 